University of Warwick institutional repository: http://go.warwick.ac.uk/wrap This paper is made available online in accordance with publisher policies. Please scroll down to view the document itself. Please refer to the repository record for this item and our policy information available from the repository home page for further information.

To see the final version of this paper please visit the publisher's website. access to the published version may require a subscription.

Author(s): Wiji Arulampalam

Article Title: The linked survival prospects of siblings: Evidence for the Indian states

Year of publication: 2008

Link to published version: http://dx.doi.org/10.1080/00324720802000176

Publisher statement: None 
This article was downloaded by: [University of Warwick]

On: 3 September 2008

Access details: Access Details: [subscription number 773571162]

Publisher Routledge

Informa Ltd Registered in England and Wales Registered Number: 1072954 Registered office: Mortimer House, 37-41 Mortimer Street, London W1T 3JH, UK

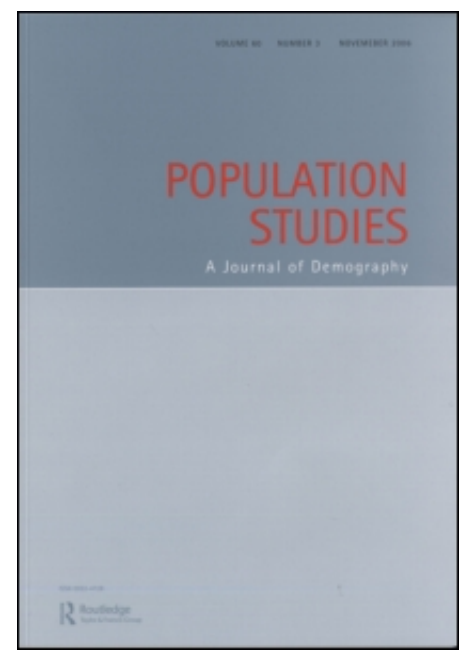

\section{Population Studies}

Publication details, including instructions for authors and subscription information:

http://www.informaworld.com/smpp/title content=t713689546

\section{The linked survival prospects of siblings: Evidence for the Indian states}

Wiji Arulampalam a; Sonia Bhalotra ${ }^{\mathrm{b}}$

a University of Warwick, ${ }^{b}$ University of Bristol,

Online Publication Date: 01 July 2008

To cite this Article Arulampalam, Wiji and Bhalotra, Sonia(2008)'The linked survival prospects of siblings: Evidence for the Indian states',Population Studies,62:2,171 - 190

To link to this Article: DOI: $10.1080 / 00324720802000176$

URL: http://dx.doi.org/10.1080/00324720802000176

\section{PLEASE SCROLL DOWN FOR ARTICLE}

\footnotetext{
Full terms and conditions of use: http://www.informaworld.com/terms-and-conditions-of-access.pdf

This article may be used for research, teaching and private study purposes. Any substantial or systematic reproduction, re-distribution, re-selling, loan or sub-licensing, systematic supply or distribution in any form to anyone is expressly forbidden.

The publisher does not give any warranty express or implied or make any representation that the contents will be complete or accurate or up to date. The accuracy of any instructions, formulae and drug doses should be independently verified with primary sources. The publisher shall not be liable for any loss, actions, claims, proceedings, demand or costs or damages whatsoever or howsoever caused arising directly or indirectly in connection with or arising out of the use of this material.
} 


\title{
The linked survival prospects of siblings: Evidence for the Indian states
}

\author{
Wiji Arulampalam ${ }^{1}$ and Sonia Bhalotra ${ }^{2}$ \\ ${ }^{1}$ University of Warwick; ${ }^{2}$ University of Bristol
}

\begin{abstract}
This paper reports an analysis of micro-data for India that shows a high correlation in infant mortality among siblings. In 13 of 15 states, we identify a causal effect of infant death on the risk of infant death of the subsequent sibling (a scarring effect), after controlling for mother-level heterogeneity. The scarring effects are large, the only other covariate with a similarly large effect being mother's (secondary or higher) education. The two states in which evidence of scarring is weak are Punjab, the richest, and Kerala, the socially most progressive. The size of the scarring effect depends upon the sex of the previous child in three states, in a direction consistent with son-preference. Evidence of scarring implies that policies targeted at reducing infant mortality will have social multiplier effects by helping avoid the death of subsequent siblings. Comparison of other covariate effects across the states offers some interesting new insights.
\end{abstract}

\begin{abstract}
Keywords: clustering; siblings; infant mortality; state dependence; scarring; unobserved heterogeneity;
\end{abstract} dynamic random-effects logit; sex; gender; India

[Submitted October 2007; Final version accepted January 2008]

\section{Introduction}

While there is considerable research on the determinants of the level of infant mortality (i.e., mortality in the first year of life), and on regional and gender inequalities in its incidence, research on inequality in the risk of death between families is relatively limited. The family is an important institution, the inherent characteristics and behavioural choices of which impact upon outcomes for children. Indeed, data from a wide spread of regions in less developed countries show strong evidence of family effects, with a small fraction of families accounting for most child deaths. Clearly, some families will have characteristics, such as a lower level of mother's education, that predispose their children to higher death risk, and many previous studies have been concerned with identifying these characteristics. Recent demographic research has shown that, on top of differences in observed characteristics, there is substantial unobserved heterogeneity between families, for example, in genetic frailty or unobserved environmental characteristics; see Das Gupta 1990; Curtis et al. 1993; Guo 1993; Zenger 1993; Sastry 1997. This paper investigates whether, in addition to inter-family heterogeneity that produces a positive correlation of sibling death risks, there is a causal process at work, whereby the actual event of the death of a child results in a higher risk of death for the next child in the family.

The basic idea is not new. It is the problem, well known in labour economics, of separating state dependence (or scarring) from unobserved heterogeneity (e.g., Heckman 1981). A contribution of our work is to bring this distinction to the analysis of the important problem of childhood death in less developed countries. In the traditional setting, state dependence refers to the dependence of an outcome (e.g., current unemployment risk) for an individual on her history of outcomes (previous unemployment spells), given her characteristics. Given the natural sequencing of siblings in time, an analogous model can be specified in which the outcome (e.g., mortality risk) for a child in a particular family can be described as a function of previous childhood deaths in that family, given family characteristics. Intuitively, the death of a child scars or marks the survival prospects of the succeeding sibling. Alternatively, defining a state as a realization of a stochastic process, one may think of state dependence at the family level in terms of infant mortality risk being dependent upon the state (died in infancy or not) 
revealed for the previous child in the family. We exploit the natural sequencing of siblings and the availability of data on the first-born child of each mother to address the classical problems that arise in the identification of endogenous effects given heterogeneity of endowments.

In our earlier work, we focused on methodological issues and, in particular, on the potential bias created by the common practice of left-truncation of the data (Arulampalam and Bhalotra 2006). In this paper, we are primarily concerned with the empirical question of how prevalent scarring is, and whether it decreases or disappears with socio-economic development. The investigation is therefore conducted using micro-data for each of the 15 major Indian states. These states are comparable in size to European countries. They exhibit large differences in social, demographic, and economic indicators (Dreze and Sen 1997). A second contribution of this paper is to investigate whether scarring effects are larger following the death of a boy rather than a girl. We can interpret state differences in these estimates by taking into account historical evidence of son-preference in the north and west of the country (Miller 1981). This paper also contributes evidence on the determinants of mortality and differences in these across the states; a survey of research on infant mortality in India (World Bank 2004) reveals how limited the evidence is.

India makes an interesting laboratory for the study of demographic processes. The size of the country means that there are large sample sizes for statistical analysis of what is a rare event, and that research will be relevant to policy directed towards improving the well-being of a large population. India contains one in six of the world's people and accounts for a quarter of the under-5 child deaths in the world (Black et al. 2003). About 70 per cent of under-5 deaths in India occur in infancy. Estimates for 1998-99 suggest that nearly $1 \frac{3}{4}$ million Indian children died before their first birthday (World Bank 2004, Introduction). Infant mortality has been declining, having halved between the early 1970s and 2000 , but the decline is less impressive than that in some (poorer) South and South-East Asian countries (Claeson et al. 2000). It is plausible that scarring has slowed the decline in mortality.

We find that, after allowing for all betweenmother differences, there is evidence of scarring in 13 of the 15 states. The two states with smaller and less significant scarring are Punjab, the richest, and Kerala, which is the most advanced socially and in its control of fertility and mortality. Scarring has large effects. Indeed, there is only one other covariate that has a marginal effect on mortality that is as big as or bigger than that associated with the survival status of a preceding sibling: this is an indicator of whether mothers have attained secondary or higher levels of education. The important role of mother's education in improving outcomes for children is now a wellestablished finding (Strauss and Thomas 1995). In contrast, only a few previous studies have considered the role of scarring in determining mortality levels (see the next section).

In 3 of the 15 states, the scarring effect is significantly larger when driven by the death of a boy as opposed to a girl. These states are Punjab, Rajasthan, and the North-Eastern cluster, and sonpreference is known to be strong in Punjab and Rajasthan. Insignificant differences by gender in scarring in the remaining twelve states are consistent with the fact that mortality differentials between boys and girls are more marked in the age range 1-5 years than in the age range of $0-1$ year that is analysed. A comparison of the effects of other covariates across the states provides some new insights. First, we find that the only state with a higher infant mortality risk for girls, other things being equal, is Punjab, the richest state. Second, although it is well known that low-caste individuals have suffered historical disadvantage in India, hard evidence on the extent and location of this disadvantage is relatively limited. We find that children of scheduled castes and tribes and other backward castes are significantly more likely to experience infant mortality in 3 of the 15 regions, namely, Punjab, Uttar Pradesh, and Rajasthan. In the other states, conditional upon other covariates like parent's education, the lower castes are not significantly more at risk.

\section{Background}

\section{Related literature}

Sibling death clustering has been highlighted in recent contributions to demographic literature. Zenger (1993) describes mechanisms that stem from the death of a child that may plausibly raise the risk of death of his or her subsequent sibling. However, the models that she estimates include either the previous sibling's survival status or mother-level unobserved heterogeneity, not both. Some other studies have included both (Curtis et al. 1993; Guo 1993; Sastry 1997; Bolstad and Manda 2001). We extend this literature by the use of different data, within which we have made regional comparisons, and by the modelling of initial conditions (mortality risk for 
first-born children) jointly with the dynamic mortality process for second and higher-order births. We argue in the Methods section that failing to do this will tend to bias the coefficient on previous child's survival status because correlations will confound its causal interpretation.

Previous studies in economics have tended to associate the observed correlation of sibling outcomes with family background (i.e., between-mother heterogeneity) (Solon et al. 1991). Several studies have used sibling data to difference out unobservable elements of family background, with the aim of identifying behavioural effects. The causal influence of interest is usually a parental choice or a policyamenable input, for example, parent's education, teenage motherhood, school years, or school quality. Outcomes studied in this way include school attainment or achievement, birth weight and foetal growth, the returns to education, wages and socioeconomic status (Behrman and Wolfe 1984; Neumark and Korenman 1994; Rosenzweig and Wolpin 1994; Altonji and Dunn 1996).

As far as we are aware, only two previous studies in the economics literature analyse data on correlated outcomes within the family with a view to disentangling genuine state dependence from unobserved heterogeneity. Heckman et al. (1985) show that the 'well-noted empirical regularity' that the successive birth-interval durations of women are positively correlated vanishes, at least for married women, once analysts control for unobservables at the woman level. As explained in the Introduction, we similarly start with an empirical regularity noted in the demographic literature, namely, that the death risks of successive siblings are positively correlated and, like Heckman et al., we seek to separate the structural from the 'spurious' explanations of this finding. In contrast to Heckman et al., we find evidence of genuine state dependence in infant mortality. The other study that is similar to ours in spirit is Oettinger (2000). He tries to identify causal effects of an individual's schooling on the schooling (attainment) of his or her younger sibling, after allowing for shared traits amongst siblings. There are other studies that analyse the effects of sibling characteristics like a child's sex on outcomes for subsequent siblings (Butcher and Case 1994; Kaestner 1997). However, sex is an exogenous variable, and the emphasis here is on causal effects flowing from endogenously determined outcomes.

There is an interesting parallel, in this respect, with the growing literature in economics and sociology on social networks and neighbourhoods. It is commonly observed that people who share residential location, race, or ethnicity have correlated outcomes. These are often associated with exogenous effects that reflect similarity of characteristics and constraints, or else that define group membership. The question motivating recent research in this area is whether there are, in addition, any endogenous effects whereby the behaviour of an individual has a causal influence on the behaviour of other members of the group (Aizer and Currie 2004; Moffitt 2004). This is similar to the problem we present in this paper if the group is a group of siblings. An interesting feature of the analysis in this case is that the reflection problem that plagues analysis of correlated effects in neighbourhoods and peer groups (Manski 1995) can be avoided by virtue of the natural sequencing of siblings by birth-order. This allowed us to re-cast the problem in terms of a dynamic model with unobserved heterogeneity where the endogenous effect is represented as a first-order Markov process, running from the survival status of a child to the survival chances of the subsequent child.

In summary, this paper presents new evidence on a problem of immense importance. The structure of the problem and the methods employed intersect with research in economics on the persistence of unemployment, on the importance of family background in determining child outcomes, and on endogenous effects in groups.

\section{Scarring mechanisms}

This section illustrates the sorts of mechanisms that might drive state dependence in infant mortality. In other words, we consider what answers there might be to the question: Why would the death of a child lead to a higher risk of death for the next child of the same mother, once all observed and unobserved differences between mothers are held constant? One mechanism is that which operates by the death of a child shortening the time to the next birth. This process may be set off in either of two ways. One possibility, which we refer to as the fecundity hypothesis, is that the death of an infant results in the mother ceasing to breastfeed and, thereby, being able to conceive sooner than otherwise (Bongaarts and Potter 1983; Kennedy and Visness 1992). An alternative is the replacement hypothesis, according to which the death of a child leads parents to (intentionally) conceive sooner in a desire to 'replace' their loss (Preston 1985). In both cases, it is a short preceding birth interval for the index child that causes an elevation of her death risk. There is plenty 
of evidence in the demographic and medical literature that short preceding birth intervals are associated with higher death risk (Cleland and Sathar 1984; Stephansson et al. 2003), especially amongst poor women (Rawlings et al. 1995). This is thought to be because it takes time for an under-nourished mother to recover physiologically from a birth, and to replenish her stock of the nutrients essential to support the next pregnancy. In India almost 40 per cent of birth intervals are shorter than 24 months (Table A1), although many studies have suggested that a minimum interval of about 24 or possibly 36 months is needed (Rutstein 2005). A further possibility is that a child death leaves the mother depressed, as a result of which her subsequent child's health is compromised, both in the womb and in early infancy; we call this the depression hypothesis. The possibility that the mother's depression is a causal factor in childhood mortality in highmortality environments has not been previously recognized in the demographic literature, but there is supporting evidence in the medical literature (Steer et al. 1992; Rahman et al. 2004).

The discussion so far indicates positive scarring effects. In fact there may be learning effects that result in the mortality risk of the index child falling on account of the death of the preceding sibling. For instance, if an older sibling dies of diarrhoea, the mother may rush to learn how to prevent diarrhoearelated infant death. Any positive degree of scarring that is identified is then net of learning effects. Although it is of policy significance to establish which mechanisms underlie state dependence and there is little definitive research in this area, this paper is concerned primarily with the prior task of identifying whether there are any state dependence effects after controlling for observed and unobserved heterogeneity. In a later section we report an investigation of the hypothesis that birth-spacing drives scarring, albeit with the qualification that birth intervals are likely to be determined jointly with mortality. Bhalotra and van Soest (2008) quantify the birthinterval-related mechanisms by endogenizing birthspacing in the context of neonatal mortality.

\section{Method and empirical analysis}

\section{The data}

The data used are from the Indian National Family Health Survey (NFHS) of 1998-99, which interviewed 92,300 ever-married women aged 15-49 at the time of the survey (IIPS and ORC Macro 2000).
They contain a complete retrospective history of births for each mother, together with a record of child deaths. We are therefore able to construct (unbalanced) panel data for mothers in which the length of the panel corresponds to the number of births. The width of the panel (number of mothers) varies between 9,370 (the North-Eastern states) and 2,340 (Kerala) (Table A1). The NFHS is one of a series of comparable Demographic Health Surveys (DHS), available for about 69 low and middleincome countries. The ideas and methods introduced in this paper are therefore immediately applicable to other regions.

\section{Descriptive statistics}

Table 1 reports mortality rates by state, which are averages over the data sample, including births across the four decades, 1961-99. Of every 1,000 children born in India over this period, 82 died in infancy. There is remarkable variation across the Indian states. For example, the large backward state of Uttar Pradesh (UP) in Central India had a mortality rate (in 1,000) of 116, while the Southern state of Kerala, known for its relative success in human development, had a rate of 36 . Table A1 presents some illustrative descriptive statistics.

The raw-data probabilities of infant death conditional on whether the preceding sibling survived infancy are displayed in Columns 2 and 3 of Table 1 . The difference of these conditional probabilities (Column 4) is a measure of the extent of death clustering. This ranges from about 0.09 in Punjab and Maharashtra to 0.18 in Bihar. These are enormous increases in risk, given an average mortality rate of 0.082 in India. Column 5 contains an alternative representation of the data in terms of the relative odds ratio, which corresponds to the coefficient on the previous child's survival status in a simple logit regression where the dependent variable is the survival status of the index child. The relative odds of a child dying in infancy if the previous sibling died rather than survived infancy lie between 2.9 and 4.8. Overall, there is a remarkable degree of death clustering in India, and this varies considerably across the states. However, these are simply the observed tendencies in the data. Estimation of the statistical model described below allows us to disentangle clustering effects into correlated risks amongst siblings and, conditional upon this, a causal effect of the death of one sibling on the risk of death of the next sibling. 
Table 1 Probabilities of infant death in 15 Indian states, 1961-99

Raw data

Estimated model

\begin{tabular}{|c|c|c|c|c|c|c|}
\hline \multirow[b]{2}{*}{ State } & \multicolumn{5}{|c|}{ Raw data } & \multirow{2}{*}{$\begin{array}{l}\text { Estimated model } \\
\text { Relative odds ratio } \\
{[p \text {-value }]} \\
{[6]^{2}}\end{array}$} \\
\hline & $\begin{array}{c}\text { Probability of death } \\
\text { [1] }\end{array}$ & $\begin{array}{c}\text { Probability of death } \\
\text { given previous sibling's } \\
\text { death } \\
{[2]}\end{array}$ & $\begin{array}{c}\text { Probability of death } \\
\text { given previous } \\
\text { sibling's survival } \\
{[3]}\end{array}$ & $\begin{array}{c}\text { Death clustering } \\
{[2]-[3]} \\
{[4]}\end{array}$ & $\begin{array}{l}\text { Relative odds ratio } \\
\qquad 5]^{1}\end{array}$ & \\
\hline \multicolumn{7}{|l|}{ Central } \\
\hline Madhya Pradesh & 0.113 & 0.223 & 0.085 & 0.138 & 3.09 & $2.05[0.000]$ \\
\hline Uttar Pradesh & 0.116 & 0.241 & 0.092 & 0.150 & 3.15 & $1.94[0.000]$ \\
\hline \multicolumn{7}{|l|}{ East } \\
\hline Orissa & 0.105 & 0.226 & 0.083 & 0.143 & 3.22 & $1.89[0.000]$ \\
\hline Bihar & 0.080 & 0.240 & 0.061 & 0.178 & 4.83 & $2.36[0.000]$ \\
\hline West Bengal & 0.076 & 0.194 & 0.060 & 0.134 & 3.79 & $1.54[0.012]$ \\
\hline \multicolumn{7}{|l|}{ North } \\
\hline Rajasthan & 0.100 & 0.211 & 0.080 & 0.131 & 3.06 & $1.94[0.000]$ \\
\hline Haryana & 0.066 & 0.202 & 0.053 & 0.149 & 4.56 & $2.50[0.000]$ \\
\hline Punjab & 0.060 & 0.143 & 0.055 & 0.088 & 2.85 & $1.43[0.130]$ \\
\hline \multicolumn{7}{|l|}{ West } \\
\hline Gujarat & 0.085 & 0.187 & 0.070 & 0.117 & 3.07 & $1.97[0.000]$ \\
\hline Maharashtra & 0.059 & 0.138 & 0.048 & 0.090 & 3.15 & $1.66[0.006]$ \\
\hline \multicolumn{7}{|l|}{ South } \\
\hline Andhra Pradesh & 0.092 & 0.190 & 0.075 & 0.115 & 2.89 & $1.43[0.020]$ \\
\hline Karnataka & 0.076 & 0.190 & 0.062 & 0.128 & 3.57 & $1.58[0.004]$ \\
\hline Tamil Nadu & 0.071 & 0.160 & 0.060 & 0.099 & 2.96 & $2.11[0.000]$ \\
\hline Kerala & 0.036 & 0.125 & 0.029 & 0.096 & 4.78 & $1.99[0.087]$ \\
\hline North-East & 0.061 & 0.166 & 0.052 & 0.114 & 3.64 & $1.71[0.000]$ \\
\hline
\end{tabular}

${ }^{1}$ The relative odds ratio is calculated as the ratio of Column [2]/(1-Column [2]) to Column [3]/(1-Column [3]). This is the exponential of the estimated scarring coefficient in a simple logit model that includes an intercept and the survival status of the previous sibling.

${ }^{2}$ Column [6] reports the equivalent numbers from the model estimates in Panel 2 of Table 2 which control for the effects of other covariates and for unobserved mother-specific effects. These are the exponentials of estimated scarring coefficient $\gamma$. The $p$-values refer to those associated with the estimated $\gamma$

Note: All probabilities are for death in infancy.

Source: National Family Health Survey II, 1998-99. 


\section{The econometric model}

Families in less developed countries often contain more than one mother. Here we are interested in siblings borne by the same mother and so we identify families with mothers. Let there be $n_{i}$ children of mother $i$. For child $j\left(j=2, \ldots, n_{i}\right)$ of mother $i(i=1,2, \ldots, N)$, the unobservable propensity to experience an infant death, $y_{i j}^{*}$, is specified as

$y_{i j}^{*}=\mathbf{x}_{i j}^{\prime} \boldsymbol{\beta}+\gamma y_{i j-1}+\alpha_{i}+u_{i j}$

where $\mathbf{x}$ is a vector of strictly exogenous observable child-specific and mother-specific characteristics that influence $y_{i j}^{*}$ and $\boldsymbol{\beta}$ is the vector of coefficients associated with $\mathbf{x}$. A child is observed to die when his or her propensity for death crosses a threshold; in this case, when $y_{i j}^{*}>0$. The model has a random intercept $\alpha_{i}$, to account for time-invariant motherspecific unobserved characteristics. This picks up any correlation of death risks among siblings arising, for example, from shared genetic characteristics or from the innate ability of their mother. In this randomeffects model the assumption of strict exogeneity of $\mathbf{x}$ implies that past, current, and future values of the variables in $\mathbf{x}$ are uncorrelated with $\alpha_{i}$.

The model also includes the observed survival status of the previous sibling, $y_{i j-1}$, the coefficient on which picks up scarring. The null of no scarring implies $\gamma=0$. The estimated parameter $\gamma$ should be interpreted as the 'average' effect of scarring over the time period considered. Equation (1) reflects the first-order Markov assumption common in models of this type (Zenger 1993), which is that, conditional on $y_{i j-1}, \mathbf{x}_{i j}$, and $\alpha_{i}$, the survival status of other older children has no impact on $y_{i j}^{*}$. If child $(j-2)$ died then, in our model, this would affect the risk of death of child $(j-1)$ and, thereby, affect the risk of death of child $j$. This is plausible since we are conditioning on $\alpha_{i}$, and any risk factors common to the siblings, $j-2, j-1$, and $j$, will be captured by $\alpha_{i}$. A model restricted to first-order effects is consistent with the mechanisms that we have suggested might drive scarring.

Equation (1) is a dynamic panel-data model, the panel consisting of a naturally time-ordered sequence of siblings within mothers. In models of this sort, the previous sibling's survival status, $y_{i j-1}$, is necessarily correlated with unobserved heterogeneity, $\alpha_{i}$. In order to identify a causal effect, one needs to take account of this correlation in the estimation. This is referred to as the 'initial conditions' problem (Heckman 1981; Wooldridge 2002). This would become unimportant if the number of children per mother were to tend to infinity but this, clearly, is not the case. In standard applications of this model, it is unusual that the start of the stochastic process of interest coincides with the start of the sample observations. Instead, the available data are typically left-truncated. However, our data contain complete retrospective histories of fertility and mortality for each mother. We are thus able to model the initial condition of the process as a natural extension of the model given in (1). We specify the equation for the first-born child of each mother as

$$
\begin{aligned}
y_{i 1}^{*} & =\mathbf{z}_{i}^{\prime} \lambda+\theta \alpha_{i}+u_{i 1} \\
i & =1, \ldots, N \text { and } j=1
\end{aligned}
$$

where $\mathbf{z}_{i}$ is a vector of strictly exogenous covariates. In general, equation (2) allows the vector of covariates $\mathbf{z}$ to differ from $\mathbf{x}$ in (1). However, we set the two vectors of covariates to be the same given that we observe the process from the start. We allow the effect of unobservable mother's characteristics in (1) and (2) to be correlated by specifying this unobservable effect as $\theta \alpha_{i}$ in (2). If we were to find that $\theta=0$ then we could conclude that unobserved heterogeneity does not enter (2), from which it would follow that the initial conditions problem was empirically unimportant. A test of the significance of $\theta$ is presented in the Results section. A potential issue with this identification strategy is that if the first conception is a miscarriage, then the first-born (live) child is not a good proxy for the initial condition of the process. In other words, the data may be implicitly left-truncated. This problem cannot be directly addressed or assessed because the data do not record miscarriages. However, in our earlier work we show that the bias associated with left-truncated data is largely redressed by modelling equation (1) jointly with a reduced-form equation like (2) for the first-observed child in the sample (Arulampalam and Bhalotra 2006). Equations (1) and (2) together specify a complete model for the infant survival process. In this way, the endogeneity of the 'lagged dependent variable', that is, the previous child's survival status, is taken into account. To the extent that this is driven by shorter birth-spacing or higher fertility, we are implicitly allowing for the effects of reproductive behaviour on mortality.

We assume that $u_{i j}$ is independently distributed as a logistic distribution $(\Lambda)$, and that the motherspecific unobservables, $\alpha_{i}$, are independent and identically distributed as normal (density $\varphi$ ). We also investigated the probit model, and found that the results were not sensitive to functional form. Marginalizing the likelihood function with respect to $\alpha_{i}$ gives, for mother $i$ 


$$
\begin{aligned}
L_{i}= & \int_{-\infty}^{\infty}\left(\prod _ { j = 2 } ^ { n _ { i } } \Lambda \left[\left(\mathbf{x}^{\prime}{ }_{i j} \boldsymbol{\beta}+\gamma y_{i j-1}+\sigma_{\alpha} \tilde{\alpha}\right)\right.\right. \\
& \left.\left.\times\left(2 y_{i j}-1\right)\right] \Lambda\left[\left(\mathbf{z}_{i}{ }_{i} \lambda+\theta \sigma_{\alpha} \tilde{\alpha}\right)\left(2 y_{i 1}-1\right)\right]\right) \\
& \times \varphi(\tilde{\alpha}) \mathrm{d} \tilde{\alpha}
\end{aligned}
$$

where $\tilde{\alpha}=\alpha / \sigma_{\alpha}$. The $\log$ likelihood function is maximized using a routine written by the authors in Stata (2004).

Previous analyses of dynamic models with unobserved heterogeneity have shown potential sensitivity of the estimates to the assumption made about the distributional form for unobserved heterogeneity, $\alpha_{i}$ (Heckman and Singer 1984). A weakness of the normality assumption is that it may not be flexible enough to account for the fact that some families never experience any child deaths and that, in some families, all children die (the mover-stayer problem). Our sample does not contain any families in which all children die in infancy. However, there are many families that experience no infant deaths, and this is accommodated by allowing for a single (empirically determined) mass at minus infinity: a very large negative value for $\alpha_{i}$ gives a very small value for $y_{i j}^{*}$, and hence a very small probability of observing death of the index child. (See Narendranathan and Elias 1993. for an application of this distributional assumption in the context of modelling individual unemployment.) The modified likelihood for mother $i$ is given as

$L_{i}^{*}=\frac{\psi}{1+\psi}\left[\prod_{j=1}^{n_{i}}\left(1-y_{i j}\right)\right]+\frac{L_{i}}{1+\psi}$

where $L_{i}$ is given by equation (3) and $\psi$ is the unknown end-point parameter. The estimated proportion of families who will have a very small $\alpha_{i}$ is given by $p$, where

$p=\frac{\psi}{1+\psi}$.

In order to ensure the non-negativity of $\psi$, it was parameterized as $\exp (\kappa)$, and $\kappa$ was estimated.

A test of $\mathrm{H}_{0}: \sigma_{\alpha}^{2}=0$ is a test that there are no unobservable characteristics of the mother in the model. This can be tested by using a likelihood ratio test (or a standard normal test) but the test statistic will not have a standard $\chi^{2}$ (or a standard normal) distribution since the parameter under the null hypothesis is on the boundary of the parameter space. The standard likelihood ratio (normal) test statistic has a probability mass of 0.5 at zero and $0.5 \chi^{2}(1)(0.5 N(0,1))$ for positive values. Thus a one-sided test of significance at the 5-per-cent level requires the use of the 10-per-cent critical value (Self and Liang 1987; Andrews 2001).

In addition to mother-specific unobserved heterogeneity, community-level random effects were allowed in order to correct the standard errors for community-level clustering in the sample design. The community effect is treated as a nuisance parameter because we cannot interpret a timeinvariant community-level effect in any meaningful manner: Children of the same mother, born at different dates, will experience different community-level effects, especially where development of community infrastructure is rapid.

\section{The empirical model}

The dependent variable and the survival status of the preceding child were both coded as binary variables - unity if the child died before the age of 12 months and zero otherwise. Since the data show some age-heaping at 6-month intervals, we investigated sensitivity of the estimates to altering the definition to include deaths at 12 months. As the results were similar, they are not reported. Children who were younger than 12 months at the time of the survey were dropped from the sample because they had not had 12 months exposure to mortality risk. When the index child was not a singleton but, instead, a twin (or triplet) then care was taken to ensure that the preceding sibling was correctly identified and was the same for each twin. When the previous child was one of a multiple birth, then $y_{i j-1}$ is defined as 1 if all children of that multiple birth died in infancy and 0 otherwise.

Child-specific regressors in the model include birth-order, sex, an indicator for whether the child is one of a multiple birth (twin, triplet, etc.), and the age of the mother at birth of the index child. For birth-order, we use a set of dummies to allow for a non-linear pattern. This may be expected given the evidence that mortality risk tends to be higher amongst first-borns than among subsequent siblings, and to then rise amongst higher birth-orders, possibly owing to maternal depletion. We include a quadratic in mother's age to allow for higher risk at younger and older ages. This is especially relevant in poor countries, where many women are teenage mothers. Mother's age at birth is, of course, related to birth-order. Other things being equal, children of higher birth-order will be born when the mother is older. Conditioning on mother's age at birth, 
'purges' the estimated birth-order effects of age effects. Mother-specific covariates in the model are her educational attainment and that of her partner, religion, and caste. These are all included as dummy variables. Cohort effects were modelled by including indicator variables for the birth-year of the mother in the intervals 1948-59, 1960-69, and 1970-84. These are expected to pick up any secular decline in death risks over time, other things being equal, and are especially important since our strategy involves using long-range retrospective histories. Conditional on mother's age at birth, including mother's birth-cohort indicator is equivalent to including the birth-year of the child. To see this, consider a woman who was born in 1940 and gave birth to the index child in 1960 so that the age of the mother at birth of the child is 20 . Since the model includes '20' and '1940', it implicitly includes '1960'.

Information on household assets, immunization, prenatal care, access to piped water, and relevant community-level variables are not used because they are time-inconsistent. These data are available at the time of the survey, while exposure to the risk of infant death in these data spanned about three decades. The same holds for breastfeeding. If we had information on breastfeeding for every child, it would help illuminate the mechanisms underlying scarring, but this information is available only for recently born children. In order to incorporate these variables we would have had to left-truncate the data. We would then have lost the first-born child of most mothers, and data on these are, as we have argued above, important in addressing the initial conditions problem. We would also have been left with too few children per mother to identify the within-mother dynamics that create scarring as distinct from mother-level heterogeneity. A further problem with incorporating these variables in the model is that they are potentially endogenous. For example, families will tend to decide simultaneously what resources to allocate to the purchase of a bicycle or a TV and what resources to allocate to attending immunization clinics to reduce the risk of child mortality. Access to facilities like piped water will be endogenous if selected families migrate to regions with these facilities, or if governments place these facilities in regions with worse health indicators (Rosenzweig and Wolpin 1986). Breastfeeding is also endogenous to the extent that children who are unhealthy at birth are often unable to suckle.

The purpose of the mother-level random effect that we include in the model is to control for the time-invariant component of these omitted variables, for example, for the fact that some mothers are more prone to breastfeed than others. Mother's age at birth and her cohort (year of birth) tends to capture trends in these omitted variables.

\section{Results}

\section{Unobserved heterogeneity}

As discussed earlier, economists have studied the extent to which the socio-economic circumstances of siblings are correlated in order to understand the force of family background and, thereby, the perpetuation of inequality across the generations (Solon et al. 1991). Demographers have interpreted motherlevel effects in mortality equations as a measure of the importance of genetic traits (Sastry 1997) or, occasionally, other variables like maternal ability (Das Gupta 1990).

Columns 8 and 9 of Table 2 present the estimated variance of the unobserved heterogeneity term and the proportion of the total error variance attributed to this. This ranges between 0.019 in Haryana and 0.212 in West Bengal. The estimates reject the null hypothesis of no mother-level unobservables in twelve states, at conventional levels of significance but, in the relatively developed states of Punjab, Haryana, Tamil Nadu, and Kerala, unobservables have limited power to explain death clustering. Previous research in demography has tended to over-estimate the contribution of fixed mother traits by virtue of neglecting scarring. In the following section, we show how our estimates of scarring levels and differences across states would change if we ignored unobserved heterogeneity.

\section{Scarring}

For ease of reference, Column 1 of Table 2 records the extent of death clustering or persistence in the raw data that was first displayed in Table 1. Estimates of scarring from a model that ignores unobserved heterogeneity are in Panel 1 and these are compared with estimates from the preferred model that allows for it in Panel 2. The marginal effect associated with $\hat{\gamma}$, the coefficient on the previous child's survival status, is computed as the difference between the sample averages of the probability of death predicted by the estimated model when $y_{i j-1}=0$ and when $y_{i j-1}=1$ (see 
Table 2 Effects of scarring on the clustering of infant mortality within families for 15 India states, 1961-99. Results from the random-effects logit regressions ${ }^{1}$

\begin{tabular}{|c|c|c|c|c|c|c|c|c|c|}
\hline \multirow[b]{2}{*}{ State } & \multirow[b]{2}{*}{$\begin{array}{c}\text { Raw data death } \\
\text { clustering } \\
{[1]}\end{array}$} & \multicolumn{3}{|c|}{ Panel 1: Model without unobserved heterogeneity } & \multicolumn{5}{|c|}{ Panel 2: Model with unobserved heterogeneity } \\
\hline & & $\begin{array}{l}\text { Estimated } \\
\text { marginal } \\
\text { effects }^{3} \\
{[2]}\end{array}$ & $\begin{array}{c}\text { Raw clustering } \\
\text { explained by } \\
\text { scarring }[2] /[1] \\
(\%) \\
{[3]}\end{array}$ & $\begin{array}{c}\text { Reduction in } \\
\text { infant mortality } \\
\text { if no scarring } \\
(\%)^{4} \\
{[4]}\end{array}$ & $\begin{array}{c}\text { Estimated } \\
\text { marginal } \\
\text { effects }^{3} \\
{[5]}\end{array}$ & $\begin{array}{c}\text { Raw clustering } \\
\text { explained by } \\
\text { scarring [6]/[1] } \\
(\%) \\
{[6]}\end{array}$ & $\begin{array}{c}\text { Reduction in } \\
\text { infant mortality } \\
\text { if no scarring } \\
(\%)^{4} \\
{[7]}\end{array}$ & $\begin{array}{c}\text { Estimated variance } \\
\text { of the mother- } \\
\text { specific } \\
\text { unobservable } \\
{[p \text {-value }]} \\
{[8]}\end{array}$ & $\begin{array}{c}\text { Estimated } \\
\text { intra-mother } \\
\text { correlation } \\
\text { coefficient }^{5} \\
\text { [9] }\end{array}$ \\
\hline \multicolumn{10}{|l|}{ Central } \\
\hline Madhya Pradesh & 0.138 & $0.117[0.000]$ & 84.4 & 10.76 & $0.067[0.000]$ & 48.6 & 10.77 & $0.309[0.000]$ & 0.084 \\
\hline Uttar Pradesh & 0.150 & $0.125[0.000]$ & 83.3 & 11.68 & $0.063[0.000]$ & 42.0 & 9.97 & $0.387[0.000]$ & 0.104 \\
\hline \multicolumn{10}{|l|}{ East } \\
\hline Orissa & 0.143 & $0.123[0.000]$ & 86.2 & 10.53 & $0.065[0.000]$ & 45.5 & 8.64 & $0.280[0.043]$ & 0.077 \\
\hline Bihar & 0.178 & $0.157[0.000]$ & 87.9 & 13.75 & $0.062[0.000]$ & 34.8 & 9.59 & $0.584[0.000]$ & 0.148 \\
\hline West Bengal & 0.134 & $0.097[0.000]$ & 72.5 & 9.88 & $0.022[0.012]$ & 16.4 & 5.39 & $0.885[0.000]$ & 0.212 \\
\hline \multicolumn{10}{|l|}{ North } \\
\hline Rajasthan & 0.131 & $0.112[0.000]$ & 85.3 & 10.19 & $0.067[0.000]$ & 51.2 & 8.67 & $0.195[0.033]$ & 0.055 \\
\hline Haryana & 0.149 & $0.127[0.000]$ & 85.0 & 11.52 & $0.092[0.000]$ & 61.8 & 9.08 & $0.064[0.370]$ & 0.019 \\
\hline Punjab & 0.088 & $0.064[0.000]$ & 72.2 & 6.05 & $0.022[0.130]$ & 25.0 & 3.07 & $0.300[0.223]$ & 0.082 \\
\hline \multicolumn{10}{|l|}{ West } \\
\hline Gujarat & 0.117 & $0.100[0.000]$ & 85.0 & 9.05 & $0.051[0.000]$ & 43.6 & 8.53 & $0.390[0.010]$ & 0.105 \\
\hline Maharashtra & 0.090 & $0.060[0.000]$ & 66.9 & 6.28 & $0.026[0.006]$ & 28.9 & 5.10 & $0.325[0.071]$ & 0.087 \\
\hline \multicolumn{10}{|l|}{ South } \\
\hline Andhra Pradesh & 0.115 & $0.086[0.000]$ & 75.0 & 7.97 & $0.026[0.020]$ & 22.6 & 4.30 & $0.454[0.021]$ & 0.119 \\
\hline Karnataka & 0.128 & $0.103[0.000]$ & 80.4 & 9.42 & $0.033[0.004]$ & 25.8 & 4.65 & $0.588[0.003]$ & 0.152 \\
\hline Tamil Nadu & 0.099 & $0.074[0.000]$ & 74.8 & 6.78 & $0.056[0.000]$ & 56.6 & 8.79 & $0.155[0.260]$ & 0.045 \\
\hline Kerala & 0.096 & $0.059[0.000]$ & 61.7 & 6.18 & $0.028[0.087]$ & 29.2 & 4.99 & $0.253[0.306]$ & 0.072 \\
\hline North-East & 0.114 & $0.093[0.000]$ & 81.2 & 8.36 & $0.028[0.000]$ & 24.6 & 4.84 & $0.694[0.000]$ & 0.174 \\
\hline
\end{tabular}

${ }^{1}$ The equation is jointly estimated with the initial condition of the process (see Model section). The marginal effect associated with scarring is significant at the 5 per cent level in all states except in Kerala, where it is significant at 9 per cent, and Punjab, where it is significant at 13 per cent (see Column 5). The $p$-values calculated to test whether the variance attributable to unobserved mother-specific heterogeneity is zero are computed accounting for the fact that the parameter under the null hypothesis is on the boundary- see the Model section.

${ }^{2}$ This is Column [4] of Table 1.

${ }^{3}$ The marginal effect is computed as the difference between the sample averages of the probability of death predicted by the estimated model when $y_{i j-1}=0$ and when $y_{i j-1}=1$ (excluding the first-born). This is approximately equivalent to the first partial derivative of the conditional probability of death of the index child with respect to the covariate, $y_{i j-1}$. The $p$-values associated with the estimated scarring coefficients are also reported.

${ }^{4}$ This is calculated as the difference between the predicted probability of death from the estimated model and the predicted probability of death from the model when $\gamma=0$ is imposed after estimation, and excluding first-born children.

${ }^{5}$ This is equal to Column [8] as a proportion of estimated total variance.

Source: National Family Health Survey II, 1998-99. 
Columns 2 and 6). These are approximately equivalent to the first partial derivative of the conditional probability of $y_{i j}=1$ with respect to $y_{i j-1}$.

The main result is that death in infancy of a previous sibling raises the probability of infant death for the index child in every state, and this result remains after controlling for a number of childspecific and mother-specific characteristics and for all unobserved differences between mothers. The scarring effect is significant at the 5-per-cent level in 13 states. In Punjab, it is significant at the 13-percent level and, in Kerala, at the 9-per-cent level.

Punjab and Kerala have the lowest mortality rates in the country. Kerala made the demographic transition ahead of the other states and its humandevelopment indicators put it in a different league from the rest of India. Punjab is the richest of India's states over the period analysed. If the fecundity and replacement mechanisms discussed earlier were the driving force in scarring, then we might expect to see relatively long birth intervals in these states. Kerala does have longer birth intervals than average but it does not stand out in this respect. The evidence from Punjab is contrary. This state has the highest fraction (21 per cent) of births with a preceding birth interval of less than 18 months (Table A1, [7]). This seeming paradox is resolved by recognizing that the birth interval is a choice variable, and that well-nourished (richer) mothers can afford to have shorter birth intervals without compromising the survival chances of their offspring (Rawlings et al. 1995). In contrast, poorer women may need a longer time to recoup from the demands of pregnancy and birth (DaVanzo and Pebley 1993). The results may, to some extent, reflect selectivity: if children conceived after a short interval are more likely to suffer miscarriage in poorer than in richer states then the mean interval in poor states will (spuriously) appear longer because our data measure the interval between births and not conceptions. For further discussion of the pattern of results across the states, see Arulampalam and Bhalotra 2004.

Comparison of Columns 2 and 6 shows that failing to control for unobserved heterogeneity can result in marginal effects that are as much as 2 or 3 times as large as the correct effect. Using the estimates in Column 6, consider how the marginal effect associated with a previous sibling's death compares with the marginal effect of other influences on mortality (in Table 5). For singleton births, no variable other than mother's having achieved secondary or higher education has a comparable effect. On average, 10 per cent of mothers have this level of education, and
9.6 per cent of children have a preceding sibling who died in infancy.

Column 6 shows the percentage of raw persistence (or clustering) that is explained by scarring. This lies between 16.4 per cent (in West Bengal) and 61.8 per cent (in Haryana). Consistent with this finding, Column 9 shows that the percentage of the error variance that is attributable to unobserved heterogeneity is smallest in Haryana and largest in West Bengal. Notice that, in Column 3, the contribution of scarring to raw clustering of mortality in these two polar cases is inflated to 72.5 per cent in West Bengal and 85 per cent in Haryana. Thus, a model that fails to allow for unobserved heterogeneity not only overestimates the level of scarring in every state, but it also under-estimates differences in scarring across the states.

Comparing the model-predicted probability of death with the predicted probability of death when scarring is set equal to zero offers an estimate of the reduction in mortality that would be achievable if scarring were eliminated. This is a useful expression of its significance. The estimates in Column 7 suggest that, in the absence of scarring, mortality rates would fall by between 3.1 per cent (in Punjab) and 10.8 per cent (in Madhya Pradesh). These estimates exclude the probability of death attached to firstborns. The pattern of results here suggests that the impact on infant mortality of eliminating scarring is smaller in states that have lower fertility levels (state-level data on fertility are given in Table A1). The estimates flowing from a model with no unobserved heterogeneity are, unsurprisingly, larger (Column 4). In addition, they produce a different state ranking, which underlines again the importance of a correct model specification.

Overall, these results have strong implications for policy, as discussed in the Introduction. Scarring involves responsive behaviour which may be amenable to policy, while unobserved heterogeneity involves largely untreatable factors like genes or fixed behavioural traits. A similar distinction between behaviour and unalterable family-specific traits is central to the nurture-nature debate (Pinker 2002). Twin studies have played a critical part in this debate. In this paper, the objective is not to identify the importance of genotypes; instead, we define all characteristics that siblings share as between-mother heterogeneity. We then seek to identify behavioural effects stimulated by an infant death on the risk of infant death for the subsequent child in the same family. 


\section{Diagnostics}

A test of the null hypothesis that $\theta=0$ in equation (2) is reported in Table 3, Column 1. This is a test of the hypothesis that the outcome for the first-born child of every mother can be treated as exogenous. To see this, observe that if $\theta=0$, then unobservables in the equation for the first observation are uncorrelated with unobservables in the (dynamic) equations for subsequent observations. The model then collapses to a simple random-effects model. The null hypothesis is rejected in 6 of the 15 states at a significance level of 10 per cent or less, underlining the potential importance of addressing the initial conditions problem.

Estimates of the parameter $p$, the mass point at minus infinity, are in Column 2 of Table 3. This is the estimated proportion of families with a very large

Table 3 Test for exogeneity of the effect of the survival of the first-born child on within-family clustering of infant mortality, Indian states, 1961-99. Model diagnostics [ $p$ values] associated with results in Panel 2 of Table 2

\begin{tabular}{|c|c|c|}
\hline State & $\begin{array}{c}\theta \\
{[1]}\end{array}$ & $\begin{array}{c}\text { Estimated } \\
\text { mass point at } \\
\text { minus infinity } \\
\psi /(1+\psi) \\
{[2]}\end{array}$ \\
\hline \multicolumn{3}{|l|}{ Central } \\
\hline Madhya Pradesh & 0.399 [0.169] & $0.025[0.281]$ \\
\hline Uttar Pradesh & $0.695[0.000]$ & $0.000[0.478]$ \\
\hline \multicolumn{3}{|l|}{ East } \\
\hline Orissa & 0.723 [0.139] & $0.145[0.026]$ \\
\hline Bihar & $1.060[0.000]$ & $0.082[0.150]$ \\
\hline West Bengal & $0.944[0.001]$ & $0.000[0.198]$ \\
\hline \multicolumn{3}{|l|}{ North } \\
\hline Rajasthan & $0.258[0.640]$ & $0.132[0.012]$ \\
\hline Haryana & $-0.341[0.942]$ & $0.325[0.000]$ \\
\hline Punjab & $1.288[0.225]$ & $0.131[0.262]$ \\
\hline \multicolumn{3}{|l|}{ West } \\
\hline Gujarat & $0.901[0.046]$ & $0.000[0.496]$ \\
\hline Maharashtra & $0.714[0.223]$ & $0.051[0.312]$ \\
\hline \multicolumn{3}{|l|}{ South } \\
\hline Andhra Pradesh & $1.300[0.010]$ & $0.055[0.285]$ \\
\hline Karnataka & 0.445 [0.139] & $0.216[0.004]$ \\
\hline Tamil Nadu & $0.263[0.864]$ & $0.043[0.397]$ \\
\hline Kerala & $1.795[0.541]$ & $0.153[0.320]$ \\
\hline North-East & $0.775[0.000]$ & $0.174[0.202]$ \\
\hline
\end{tabular}

Notes: $\theta$ and $\psi /(1+\psi)$ are defined in The Econometric Model section, see equations (2), (4) and (5). The $p$-values reported in Column [2] are computed accounting for the fact that the parameter under the null hypothesis is on the boundary - see The Econometric Model section.

Source: National Family Health Survey II, 1998-99. negative value of $\alpha_{i}$, indicating a very low probability of infant death in the family. It is significant in 4 of the 15 states (at less than the 10-per-cent level), demonstrating the practical relevance of allowing for departures from normality in some cases. In line with the discussion above, this number is large in the low-mortality state of Haryana, and much smaller in high-mortality states like Uttar Pradesh.

\section{Alternative specifications}

In this section we report the results of alternative model specifications: first, whether scarring is driven entirely by birth-spacing, and then whether there is evidence of son-preference. We also discuss sensitivity of the estimated effects to the age-composition of mothers, and to the estimator. In Table 4 we present only the scarring coefficients; full results are available from the authors.

The reference model is that in Panel 2 of Table 2. These results are displayed again in Column 1 of Table 4. This model takes a long time to converge because it allows a probability mass at negative infinity. We have already seen that this mass point is significant in 4 of the 15 states (Table 3, Column 2). We first show that the scarring coefficients are robust to neglecting the mass point. We then show the results of estimating a more restrictive model with $\psi=0$ (no mass points); see Column 2 of Table 4. In the four states in which the mass point is significant, namely, Orissa, Rajasthan, Haryana, and Karnataka, the estimates of scarring in Column 2 are a bit larger than in Column 1, but the differences are not so large as to change our qualitative conclusions. The rest of this section shows estimates of variants of the main model applying the restriction that there is no mass point.

As discussed in the Introduction, short birthspacing is a potential mechanism driving scarring. Since birth-spacing is amenable to policy interventions such as extension of contraception provision, it is useful to confirm this speculation. Column 3 of Table 4 presents estimates obtained after including dummy variables indicating the length of the preceding interval as less than 18, 18-23, 24-29 months, or longer. These categories were chosen by reference to results in the demographic literature that suggest relevant thresholds (Cleland and Sathar 1984; Curtis et al. 1993), and by reference to the distribution of birth intervals in our data. The coefficient on previous sibling's survival status is now smaller. Additionally, in the two states of Punjab and Kerala and to a lesser extent in the three states of West 
Table 4 Effects of birth-spacing and son-preference on within-family clustering of infant mortality in 15 Indian states, 1961-99. Estimated scarring coefficients ( $\gamma)$ from model extensions [ $p$-values]

\begin{tabular}{|c|c|c|c|c|c|c|}
\hline State & $\begin{array}{l}\text { Preferred model allowing } \\
\text { for mass point at }-\infty \\
\text { (Table 2: Column [6]) } \\
\text { Model } 1 \\
{[1]}\end{array}$ & $\begin{array}{c}\text { Exclude mass point } \\
\text { at }-\infty \\
\text { Model } 2 \\
{[2]}\end{array}$ & $\begin{array}{l}\text { Add dummies for } \\
\text { preceding birth } \\
\text { intervals } \\
\text { Model } 3 \\
\text { [3] }\end{array}$ & $\begin{array}{c}\text { Allow previous child's } \\
\text { survival status to be } \\
\text { gender specific: base- } \\
\text { line effects } \\
\text { Model } 4 \\
{[4]}\end{array}$ & $\begin{array}{l}\text { Allow previous child's } \\
\text { survival status to be } \\
\text { gender specific: } \\
\text { interaction effects } \\
\text { Model } 4 \\
{[5]}\end{array}$ & $\begin{array}{c}\text { Add mother's age at } \\
\text { birth of index child aver- } \\
\text { aged over all children, } \\
\text { and its square } \\
\text { Model } 5 \\
{[6]}\end{array}$ \\
\hline \multicolumn{7}{|l|}{ Central } \\
\hline Madhya Pradesh & 0.719 [0.000] & $0.732[0.000]$ & $0.561[0.000]$ & $0.751[0.000]$ & $-0.043[0.710]$ & $0.702[0.000]$ \\
\hline Uttar Pradesh & $0.662[0.000]$ & $0.663[0.000]$ & $0.530[0.000]$ & $0.629[0.000]$ & $0.072[0.444]$ & $0.671[0.000]$ \\
\hline \multicolumn{7}{|l|}{ East } \\
\hline Orissa & $0.639[0.000]$ & $0.671[0.000]$ & $0.489[0.000]$ & $0.743[0.000]$ & $-0.169[0.320]$ & $0.658[0.000]$ \\
\hline Bihar & $0.859[0.000]$ & $0.862[0.000]$ & $0.705[0.000]$ & $0.931[0.000]$ & $-0.145[0.310]$ & $0.834[0.000]$ \\
\hline West Bengal & $0.429[0.012]$ & $0.407[0.016]$ & $0.304[0.079]$ & $0.324[0.102]$ & $0.188[0.401]$ & $0.335[0.047]$ \\
\hline \multicolumn{7}{|l|}{ North } \\
\hline Rajasthan & $0.663[0.000]$ & $0.691[0.000]$ & $0.516[0.000]$ & $0.799[0.000]$ & $-0.257[0.046]$ & $0.710[0.000]$ \\
\hline Haryana & $0.916[0.000]$ & $0.987[0.000]$ & $0.844[0.000]$ & $1.147[0.000]$ & $-0.350[0.188]$ & $0.918[0.000]$ \\
\hline Punjab & $0.360[0.130]$ & $0.348[0.153]$ & $0.167[0.499]$ & $0.670[0.015]$ & $-0.727[0.038]$ & 0.197 [0.413] \\
\hline \multicolumn{7}{|l|}{ West } \\
\hline Gujarat & $0.676[0.000]$ & $0.681[0.000]$ & $0.587[0.000]$ & $0.591[0.001]$ & $0.195[0.346]$ & $0.633[0.000]$ \\
\hline Maharashtra & $0.506[0.006]$ & $0.542[0.003]$ & $0.323[0.089]$ & $0.393[0.077]$ & $0.319[0.200]$ & $0.439[0.017]$ \\
\hline \multicolumn{7}{|l|}{ South } \\
\hline Andhra Pradesh & $0.360[0.020]$ & $0.373[0.017]$ & $0.270[0.089]$ & $0.300[0.114]$ & $0.143[0.491]$ & $0.292[0.066]$ \\
\hline Karnataka & $0.457[0.004]$ & $0.482[0.003]$ & $0.384[0.021]$ & $0.461[0.017]$ & $0.046[0.837]$ & $0.460[0.000]$ \\
\hline Tamil Nadu & $0.746[0.000]$ & $0.748[0.000]$ & $0.639[0.001]$ & $0.825[0.000]$ & $-0.175[0.470]$ & $0.663[0.000]$ \\
\hline Kerala & $0.687[0.087]$ & $0.720[0.074]$ & $0.592[0.149]$ & $0.324[0.522]$ & $0.814[0.131]$ & $0.683[0.123]$ \\
\hline North-East & $0.535[0.000]$ & $0.531[0.000]$ & 0.391 [0.001] & $0.715[0.000]$ & $-0.463[0.003]$ & $0.515[0.000]$ \\
\hline
\end{tabular}

Notes: The equation is jointly estimated with the initial condition of the process (see the Methods section). Models 3-5 are extensions of Model 2. Model 3 includes binary indicators for the duration of the preceding birth interval being less than 18 months, $18-23$ months, and 24-29 months. Model 4 includes an interaction term between a dummy indicating that the previous child was a girl, and the previous child's survival status. Model 5 investigates an alternative estimator.

Source: National Family Health Survey II, 1998-99. 
Bengal, Maharashtra, and Andhra Pradesh, it seems possible that birth-spacing is the main causal mechanism in scarring. In the other states, it seems that some further causal processes are also at work. An example of a causal process that may operate independently of birth-interval length is mother's depression (Background section). Although we do not allow for endogeneity of the birth interval, this finding is consistent with the findings of Bhalotra and van Soest (2008) for the state of Uttar Pradesh, which account for endogeneity.

Following an infant death, it may be argued that son-preference will lead parents to hasten to replace this child more quickly if it was a boy rather than a girl. If so, to the extent that scarring reflects short birth-spacing, we might expect a larger scarring effect when the previous death is of a boy. This was investigated by interacting the previous child's survival status with a dummy indicating this child's sex. Table 4, Column 4 shows the base coefficients (for boys), while Column 5 shows the coefficient on the interaction term. The interaction is significant in 3 of the 15 states with the expected (negative) sign. While Rajasthan and Punjab are known to be regions with strong son-preference, the significance of this effect for the North-East is somewhat unexpected. These results are only indicative. A more complete analysis of son-preference would condition upon whether or not the family had a surviving boy (i.e., not just whether the immediately preceding child was a surviving boy).

We have already discussed the perils of leftcensoring and avoided this. Here we turn our attention to issues of right-censoring. To avoid right-censoring of the mortality data, we have dropped children born in the 12 months before the survey date. What about right-censoring of fertility, the fact that not all women have, at the time of the survey, completed their fertility? There is no direct mechanism by which future births of the mother will have an impact on the mortality risk of the index child. However, right-censoring will 'bias' the agecomposition of mothers in the sample. Our estimates condition upon mother's age at birth but it is possible that this additive control is not adequate. The direction of any remaining effect is difficult to pin down because it involves age, cohort, and time effects. In particular, the extent of scarring may depend upon calendar time as well as upon the agecomposition of mothers in the sample.

As a check on whether our results are affected by right-censoring of fertility, we re-estimated the model, restricting the sample to women who were beyond childbearing age (40-49 years) and can be assumed to have completed their fertility. We expected the scarring coefficient to be different for this sample because of time (cohort) effects. But if it turned out to be close to zero, we would have been concerned that our main results had been driven by a failure to correct fully for right-censoring. To avoid small sample sizes and also to avoid displaying 15 state-specific equations, this check was done after pooling the data for the 15 states and conditioning upon state fixed effects. The estimated scarring coefficient is 0.823 . This is significant and in fact larger than the coefficient of 0.652 obtained when an identical model was estimated on all mothers. The detailed results are available from the authors on request.

So far we have assumed that mother-specific unobservables are captured by a random effect $\left(\alpha_{i}\right)$, and that the covariates $(\mathbf{x})$ are strictly exogenous. Treating the $\alpha_{i}$ as fixed effects (parameters) and estimating them along with the other parameters of the model gives rise to the incidental parameters' problem (Neyman and Scott 1948). An alternative that relaxes the assumption of strict exogeneity of $\mathbf{x}$ is to estimate the model parameters using conditional maximum likelihood (CML), which involves conditioning upon a set of statistics sufficient for the elimination of $\alpha_{i}$ (Chamberlain 1984; Narendranathan and Elias 1993 present an application). A set of sufficient statistics can be found in the case of a dynamic model under the restrictions that the covariate effects are zero $(\boldsymbol{\beta}=$ $0)$, that the error $\left(u_{i j}\right)$ distribution is logistic, and that there are at least four children per mother $(j \geq$ 4). The CML estimator involves a considerable loss of information. For example, only the subset of families that have experienced at least one death contribute to the CMLE. Another disadvantage is that it does not yield marginal or average partial effects (Wooldridge 2005). We therefore investigated the robustness of our estimates to the random-effects assumption by including in the model the time average of the time-varying covariates (Chamberlain 1984). The only covariate that varies across siblings in our model is the age of the mother at the birth of the index child. We included the average of this across children, and the square of the average in the model to capture any correlation between the $\mathbf{x}$ and $\alpha_{i}$. The results from this are reported in Column 6 of Table 4. There are no qualitative changes to the results. 


\section{Other covariates}

The effects of the other covariates (x) for our preferred model (Table 4, Column 1) are reported in Table 5. These effects are conditional upon the preceding sibling's survival status $\left(y_{i j-1}\right)$ and a mother-level random effect $\left(\alpha_{i}\right)$. They are therefore not strictly comparable with previous results in the literature obtained from the estimation of simple reduced-form logit or probit models of mortality.

The effects of the child's sex are largely insignificant in most states. What is striking here is that girls suffer excess mortality in Punjab (the richest state), the difference, at 0.028 points, being about half of the average risk in this state, which is 0.06 . In contrast, girls have a survival advantage in West Bengal and the North-Eastern states. This is not unexpected since girls are born with better survival chances than boys, which tend to be gradually eroded as the role of environmental factors increases with age. If the dependent variables were defined as death risk conditional on survival till the age of 6 months, we would almost certainly see a relative disadvantage for girls in more of the Indian states. Multiple births suffer substantially higher risks in all states, consistent with previous evidence. Infant death risk is non-linear in birth-order, dipping for second-borns. Higher education amongst fathers and mothers shows significant effects in about half the states, but the pattern of effects shows no obvious relation with the socio-economic position of the state. Infant mortality is U-shaped in mother's age at birth in every state.

The disadvantaged castes suffer higher mortality risk only in the states of Punjab, Uttar Pradesh, and Rajasthan. Scheduled castes (SC) are a low-caste group, designated SC because of their listing in a schedule appended to the Constitution of India. Scheduled tribes (ST), enumerated in another schedule, fall outside the Hindu caste system but their members are, like the SC, among the poorest in society (Gang et al. 2002). In India as a whole, SC account for about 18 and ST for about 8 per cent of the population.

Children in Muslim households enjoy lower death risks in four states: Andhra, Maharashtra, Uttar Pradesh, and Rajasthan. The risk of infant death has declined over time. We estimate that children of mothers who were born before 1960 were between 2 and 7 percentage points more likely to die than children of mothers born after 1970, ceteris paribus.

\section{Conclusions}

Development progress is now widely measured with reference to the Millennium Development Goals (MDG), one of which is to reduce under-5 mortality by two-thirds by 2015, relative to its level in 1990 (see UNDP 2003). This has resulted in renewed interest in research and policy design in this area. See, for example, various issues of the Lancet (2003) on child survival. This paper contributes new insights into the determinants of infant mortality.

Across the less developed world, where fertility and childhood mortality rates are high, some families experience multiple child deaths while others experience none. In attempting to explain this phenomenon, we proposed and investigated the hypothesis that the event of a child death creates a dynamic that makes further children of the same mother more vulnerable to early death. Separating causality from correlation in this area has important implications for policy and for research on the inter-relations of family behaviour, mortality, and fertility.

We find a great deal of clustering of mortality within families in each of the 15 Indian states for which data are analysed. Unconditional probabilities show that a child whose previous sibling died in infancy is 3-4 times as likely to experience infant death as a child whose previous sibling survived. Using data on 223,702 children spread across the 15 major states of India, we estimated the size of scarring effects conditional upon mother-level unobservables. We report the identification of sizeable scarring effects in 13 of the 15 states. The relative odds of infant death conditional upon the preceding sibling dying in infancy range between 1.4 and 2.5. The percentage of the observed clustering of sibling deaths that is explained by scarring ranges between 16 per cent in West Bengal and 62 per cent in Haryana. Previous research on death clustering has tended to equate sibling death clustering with between-mother differences, ignoring these large within-mother effects. We estimate that eliminating scarring would reduce infant mortality rates among second and higher-order children by between 3.1 per cent (Punjab) and 10.8 per cent (Madhya Pradesh). In view of the fact that the rate of decline of child mortality in 1990-2001 was 1.1 per cent per annum and during 1960-90 it was 2.5 per cent per annum (Black et al. 2003), these are large potential changes.

Our results highlight the role of short birth intervals and, possibly, mother's depression as causal 
Table 5 Marginal effects [ $p$-values] of the covariates for the preferred model (Table 4, Column [1]), 15 Indian states, 1961-99

\begin{tabular}{|c|c|c|c|c|c|c|c|c|c|c|c|c|c|c|c|}
\hline & $\begin{array}{l}\text { Madhya } \\
\text { Pradesh }\end{array}$ & $\begin{array}{l}\text { Uttar } \\
\text { Pradesh }\end{array}$ & Orissa & Bihar & $\begin{array}{l}\text { West } \\
\text { Bengal }\end{array}$ & Rajasthan & Haryana & Punjab & Gujarat & Maharashtra & $\begin{array}{l}\text { Andhra } \\
\text { Pradesh }\end{array}$ & Karnataka & $\begin{array}{l}\text { Tamil } \\
\text { Nadu }\end{array}$ & Kerala & North-East \\
\hline Female & $\begin{array}{c}-0.007 \\
{[0.224]}\end{array}$ & $\begin{array}{c}0.004 \\
{[0.440]}\end{array}$ & $\begin{array}{c}-0.006 \\
{[0.419]}\end{array}$ & $\begin{array}{c}0.007 \\
{[0.146]}\end{array}$ & $\begin{array}{c}-0.015 \\
{[0.041]}\end{array}$ & $\begin{array}{r}0.003 \\
{[0.564]}\end{array}$ & $\begin{array}{r}0.009 \\
{[0.214]}\end{array}$ & $\begin{array}{c}0.028 \\
{[0.000]}\end{array}$ & $\begin{array}{c}-0.012 \\
{[0.109]}\end{array}$ & $\begin{array}{c}-0.000 \\
{[0.938]}\end{array}$ & $\begin{array}{c}-0.002 \\
{[0.784]}\end{array}$ & $\begin{array}{c}-0.004 \\
{[0.616]}\end{array}$ & $\begin{array}{c}-0.003 \\
{[0.653]}\end{array}$ & $\begin{array}{c}-0.008 \\
{[0.062]}\end{array}$ & $\begin{array}{c}-0.008 \\
{[0.018]}\end{array}$ \\
\hline \multicolumn{16}{|l|}{$\begin{array}{l}\text { Mother's year of birth - after } \\
1970 \text { (base) }\end{array}$} \\
\hline Pre-1959 & $\begin{array}{c}0.043 \\
{[0.000]}\end{array}$ & $\begin{array}{c}0.068 \\
{[0.000]}\end{array}$ & $\begin{array}{c}0.035 \\
{[0.003]}\end{array}$ & $\begin{array}{c}0.018 \\
{[0.023]}\end{array}$ & $\begin{array}{c}0.064 \\
{[0.000]}\end{array}$ & $\begin{array}{c}0.045 \\
{[0.000]}\end{array}$ & $\begin{array}{c}0.032 \\
{[0.010]}\end{array}$ & $\begin{array}{c}0.020 \\
{[0.103]}\end{array}$ & $\begin{array}{c}0.041 \\
{[0.001]}\end{array}$ & $\begin{array}{c}0.028 \\
{[0.001]}\end{array}$ & $\begin{array}{c}0.048 \\
{[0.000]}\end{array}$ & $\begin{array}{c}0.036 \\
{[0.001]}\end{array}$ & $\begin{array}{c}0.020 \\
{[0.063]}\end{array}$ & $\begin{array}{c}0.053 \\
{[0.007]}\end{array}$ & $\begin{array}{c}0.020 \\
{[0.001]}\end{array}$ \\
\hline $1960-69$ & $\begin{array}{c}0.0193 \\
{[0.021]}\end{array}$ & $\begin{array}{c}0.026 \\
{[0.000]}\end{array}$ & $\begin{array}{c}0.004 \\
{[0.748]}\end{array}$ & $\begin{array}{c}0.016 \\
{[0.039]}\end{array}$ & $\begin{array}{c}0.017 \\
{[0.181]}\end{array}$ & $\begin{array}{c}0.024 \\
{[0.005]}\end{array}$ & $\begin{array}{c}0.015 \\
{[0.201]}\end{array}$ & $\begin{array}{c}0.010 \\
{[0.374]}\end{array}$ & $\begin{array}{c}0.013 \\
{[0.267]}\end{array}$ & $\begin{array}{c}0.012 \\
{[0.135]}\end{array}$ & $\begin{array}{c}0.026 \\
{[0.035]}\end{array}$ & $\begin{array}{c}0.026 \\
{[0.016]}\end{array}$ & $\begin{array}{c}0.002 \\
{[0.875]}\end{array}$ & $\begin{array}{c}0.039 \\
{[0.051]}\end{array}$ & $\begin{array}{c}0.009 \\
{[0.125]}\end{array}$ \\
\hline \multicolumn{16}{|l|}{ Religion—Hindu (base) } \\
\hline Muslim & $\begin{array}{c}-0.011 \\
{[0.411]}\end{array}$ & $\begin{array}{l}-0.032 \\
{[0.000]}\end{array}$ & $\begin{array}{c}-0.020 \\
{[0.473]}\end{array}$ & $\begin{array}{l}-0.004 \\
{[0.640]}\end{array}$ & $\begin{array}{l}-0.003 \\
{[0.768]}\end{array}$ & $\begin{array}{c}-0.023 \\
{[0.037]}\end{array}$ & $\begin{array}{c}-0.012 \\
{[0.460]}\end{array}$ & $\begin{array}{l}-0.024 \\
{[0.330]}\end{array}$ & $\begin{array}{c}-0.013 \\
{[0.403]}\end{array}$ & $\begin{array}{l}-0.021 \\
{[0.040]}\end{array}$ & $\begin{array}{c}-0.045 \\
{[0.033]}\end{array}$ & $\begin{array}{l}-0.016 \\
{[0.245]}\end{array}$ & $\begin{array}{c}-0.017 \\
{[0.248]}\end{array}$ & $\begin{array}{l}0.002 \\
{[0.852]}\end{array}$ & $\begin{array}{c}0.009 \\
{[0.207]}\end{array}$ \\
\hline Other & $\begin{array}{c}0.001 \\
{[0.961]}\end{array}$ & $\begin{array}{l}-0.031 \\
{[0.343]}\end{array}$ & $\begin{array}{r}0.006 \\
{[0.854]}\end{array}$ & $\begin{array}{c}-0.006 \\
{[0.823]}\end{array}$ & $\begin{array}{r}0.002 \\
{[0.956]}\end{array}$ & $\begin{array}{r}-0.070 \\
{[0.047]}\end{array}$ & $\begin{array}{l}-0.004 \\
{[0.807]}\end{array}$ & $\begin{array}{c}-0.008 \\
{[0.322]}\end{array}$ & $\begin{array}{l}-0.067 \\
{[0.174]}\end{array}$ & $\begin{array}{c}-0.002 \\
{[0.817]}\end{array}$ & $\begin{array}{l}-0.030 \\
{[0.133]}\end{array}$ & $\begin{array}{l}-0.007 \\
{[0.829]}\end{array}$ & $\begin{array}{c}-0.014 \\
{[0.437]}\end{array}$ & $\begin{array}{r}0.015 \\
{[0.216]}\end{array}$ & $\begin{array}{c}0.002 \\
{[0.702]}\end{array}$ \\
\hline \multicolumn{16}{|l|}{ Ethnicity—other (base) } \\
\hline Scheduled caste/tribe & $\begin{array}{c}0.013 \\
{[0.200]}\end{array}$ & $\begin{array}{c}0.012 \\
{[0.080]}\end{array}$ & $\begin{array}{c}-0.010 \\
{[0.390]}\end{array}$ & $\begin{array}{c}0.011 \\
{[0.258]}\end{array}$ & $\begin{array}{r}0.012 \\
{[0.263]}\end{array}$ & $\begin{array}{c}0.008 \\
{[0.278]}\end{array}$ & $\begin{array}{c}-0.004 \\
{[0.675]}\end{array}$ & $\begin{array}{c}0.019 \\
{[0.049]}\end{array}$ & $\begin{array}{c}-0.001 \\
{[0.893]}\end{array}$ & $\begin{array}{c}0.003 \\
{[0.684]}\end{array}$ & $\begin{array}{c}0.015 \\
{[0.260]}\end{array}$ & $\begin{array}{c}-0.005 \\
{[0.694]}\end{array}$ & $\begin{array}{c}-0.038 \\
{[0.196]}\end{array}$ & $\begin{array}{c}0.018 \\
{[0.168]}\end{array}$ & $\begin{array}{c}-0.008 \\
{[0.157]}\end{array}$ \\
\hline Other backward caste & $\begin{array}{c}0.018 \\
{[0.053]}\end{array}$ & $\begin{array}{c}0.018 \\
{[0.004]}\end{array}$ & $\begin{array}{r}-0.009 \\
{[0.401]}\end{array}$ & $\begin{array}{c}0.013 \\
{[0.133]}\end{array}$ & $\begin{array}{c}0.025 \\
{[0.236]}\end{array}$ & $\begin{array}{c}-0.012 \\
{[0.143]}\end{array}$ & $\begin{array}{c}-0.003 \\
{[0.766]}\end{array}$ & $\begin{array}{c}0.016 \\
{[0.150]}\end{array}$ & $\begin{array}{r}0.009 \\
{[0.393]}\end{array}$ & $\begin{array}{c}0.005 \\
{[0.514]}\end{array}$ & $\begin{array}{c}0.008 \\
{[0.511]}\end{array}$ & $\begin{array}{c}-0.015 \\
{[0.175]}\end{array}$ & $\begin{array}{r}-0.033 \\
{[0.257]}\end{array}$ & $\begin{array}{c}0.006 \\
{[0.501]}\end{array}$ & $\begin{array}{c}0.003 \\
{[0.713]}\end{array}$ \\
\hline \multicolumn{16}{|l|}{$\begin{array}{l}\text { Mother's s education-none } \\
\text { (base) }\end{array}$} \\
\hline Incomplete primary & $\begin{array}{c}-0.011 \\
{[0.326]}\end{array}$ & $\begin{array}{c}-0.019 \\
{[0.149]}\end{array}$ & $\begin{array}{c}-0.008 \\
{[0.532]}\end{array}$ & $\begin{array}{c}-0.032 \\
{[0.060]}\end{array}$ & $\begin{array}{c}-0.005 \\
{[0.602]}\end{array}$ & $\begin{array}{c}0.009 \\
{[0.528]}\end{array}$ & $\begin{array}{c}0.018 \\
{[0.409]}\end{array}$ & $\begin{array}{c}0.016 \\
{[0.380]}\end{array}$ & $\begin{array}{c}-0.011 \\
{[0.379]}\end{array}$ & $\begin{array}{c}-0.003 \\
{[0.751]}\end{array}$ & $\begin{array}{c}-0.019 \\
{[0.268]}\end{array}$ & $\begin{array}{c}-0.003 \\
{[0.841]}\end{array}$ & $\begin{array}{c}-0.003 \\
{[0.809]}\end{array}$ & $\begin{array}{c}-0.023 \\
{[0.030]}\end{array}$ & $\begin{array}{c}-0.009 \\
{[0.102]}\end{array}$ \\
\hline Complete primary & $\begin{array}{c}-0.021 \\
{[0.125]}\end{array}$ & $\begin{array}{l}-0.020 \\
{[0.063]}\end{array}$ & $\begin{array}{r}-0.002 \\
{[0.913]}\end{array}$ & $\begin{array}{l}-0.014 \\
{[0.502]}\end{array}$ & $\begin{array}{r}-0.059 \\
{[0.030]}\end{array}$ & $\begin{array}{c}-0.007 \\
{[0.612]}\end{array}$ & $\begin{array}{l}-0.021 \\
{[0.179]}\end{array}$ & $\begin{array}{c}-0.023 \\
{[0.071]}\end{array}$ & $\begin{array}{l}-0.018 \\
{[0.280]}\end{array}$ & $\begin{array}{r}0.005 \\
{[0.682]}\end{array}$ & $\begin{array}{c}0.003 \\
\lceil 0.870]\end{array}$ & $\begin{array}{l}-0.022 \\
{[0.279]}\end{array}$ & $\begin{array}{l}-0.005 \\
{[0.639]}\end{array}$ & $\begin{array}{l}-0.009 \\
{[0.501]}\end{array}$ & $\begin{array}{c}-0.010 \\
{[0.319]}\end{array}$ \\
\hline Incomplete secondary & $\begin{array}{r}-0.006 \\
{[0.684]}\end{array}$ & $\begin{array}{c}-0.018 \\
{[0.154]}\end{array}$ & $\begin{array}{c}-0.019 \\
{[0.249]}\end{array}$ & $\begin{array}{c}-0.015 \\
{[0.260]}\end{array}$ & $\begin{array}{c}-0.064 \\
{[0.000]}\end{array}$ & $\begin{array}{c}-0.022 \\
{[0.129]}\end{array}$ & $\begin{array}{l}-0.021 \\
{[0.227]}\end{array}$ & $\begin{array}{r}0.017 \\
{[0.212]}\end{array}$ & $\begin{array}{c}-0.031 \\
{[0.029]}\end{array}$ & $\begin{array}{c}-0.016 \\
{[0.085]}\end{array}$ & $\begin{array}{c}-0.043 \\
{[0.049]}\end{array}$ & $\begin{array}{l}-0.027 \\
{[0.075]}\end{array}$ & $\begin{array}{c}-0.002 \\
{[0.876]}\end{array}$ & $\begin{array}{r}-0.020 \\
{[0.085]}\end{array}$ & $\begin{array}{c}-0.013 \\
{[0.044]}\end{array}$ \\
\hline $\begin{array}{l}\text { Complete secondary or } \\
\text { higher }\end{array}$ & $\begin{array}{r}-0.089 \\
{[0.000]}\end{array}$ & $\begin{array}{c}-0.075 \\
{[0.000]}\end{array}$ & $\begin{array}{c}-0.053 \\
{[0.153]}\end{array}$ & $\begin{array}{c}-0.034 \\
{[0.076]}\end{array}$ & $\begin{array}{r}-0.038 \\
{[0.202]}\end{array}$ & $\begin{array}{c}-0.037 \\
{[0.088]}\end{array}$ & $\begin{array}{c}-0.006 \\
{[0.747]}\end{array}$ & $\begin{array}{c}-0.013 \\
{[0.442]}\end{array}$ & $\begin{array}{c}-0.049 \\
{[0.015]}\end{array}$ & $\begin{array}{l}-0.000 \\
{[0.988]}\end{array}$ & $\begin{array}{c}-0.001 \\
{[0.986]}\end{array}$ & $\begin{array}{l}-0.011 \\
{[0.581]}\end{array}$ & $\begin{array}{c}-0.007 \\
{[0.698]}\end{array}$ & $\begin{array}{c}-0.035 \\
{[0.034]}\end{array}$ & $\begin{array}{c}-0.003 \\
{[0.786]}\end{array}$ \\
\hline \multicolumn{16}{|l|}{$\begin{array}{l}\text { Father's education-none } \\
\text { (base) }\end{array}$} \\
\hline Incomplete primary & $\begin{array}{r}0.004 \\
{[0.697]}\end{array}$ & $\begin{array}{c}0.017 \\
{[0.095]}\end{array}$ & $\begin{array}{c}-0.006 \\
{[0.621]}\end{array}$ & $\begin{array}{c}0.004 \\
{[0.695]}\end{array}$ & $\begin{array}{c}-0.007 \\
{[0.512]}\end{array}$ & $\begin{array}{c}0.009 \\
{[0.365]}\end{array}$ & $\begin{array}{c}-0.025 \\
{[0.196]}\end{array}$ & $\begin{array}{c}0.012 \\
{[0.516]}\end{array}$ & $\begin{array}{c}-0.012 \\
{[0.279]}\end{array}$ & $\begin{array}{c}0.007 \\
{[0.416]}\end{array}$ & $\begin{array}{c}-0.013 \\
{[0.396]}\end{array}$ & $\begin{array}{c}-0.018 \\
{[0.149]}\end{array}$ & $\begin{array}{c}-0.004 \\
{[0.706]}\end{array}$ & $\begin{array}{c}0.004 \\
{[0.713]}\end{array}$ & $\begin{array}{c}-0.005 \\
{[0.428]}\end{array}$ \\
\hline Complete primary & $\begin{array}{c}-0.004 \\
{[0.719]}\end{array}$ & $\begin{array}{l}-0.019 \\
{[0.035]}\end{array}$ & $\begin{array}{r}-0.006 \\
{[0.656]}\end{array}$ & $\begin{array}{c}-0.006 \\
{[0.648]}\end{array}$ & $\begin{array}{c}0.009 \\
{[0.600]}\end{array}$ & $\begin{array}{c}-0.004 \\
{[0.693]}\end{array}$ & $\begin{array}{c}-0.030 \\
{[0.079]}\end{array}$ & $\begin{array}{c}-0.021 \\
{[0.146]}\end{array}$ & $\begin{array}{l}-0.027 \\
{[0.094]}\end{array}$ & $\begin{array}{r}0.006 \\
{[0.609]}\end{array}$ & $\begin{array}{c}0.004 \\
{[0.753]}\end{array}$ & $\begin{array}{l}-0.042 \\
{[0.017]}\end{array}$ & $\begin{array}{c}-0.010 \\
{[0.368]}\end{array}$ & $\begin{array}{c}-0.002 \\
{[0.905]}\end{array}$ & $\begin{array}{c}-0.013 \\
{[0.148]}\end{array}$ \\
\hline Incomplete secondary & $\begin{array}{r}-0.008 \\
{[0.369]}\end{array}$ & $\begin{array}{l}-0.017 \\
{[0.021]}\end{array}$ & $\begin{array}{r}-0.029 \\
{[0.021]}\end{array}$ & $\begin{array}{r}-0.009 \\
{[0.267]}\end{array}$ & $\begin{array}{r}-0.004 \\
{[0.737]}\end{array}$ & $\begin{array}{r}-0.009 \\
{[0.272]}\end{array}$ & $\begin{array}{r}-0.020 \\
{[0.069]}\end{array}$ & $\begin{array}{c}-0.003 \\
{[0.814]}\end{array}$ & $\begin{array}{c}-0.006 \\
{[0.558]}\end{array}$ & $\begin{array}{c}-0.005 \\
{[0.562]}\end{array}$ & $\begin{array}{l}-0.020 \\
{[0.172]}\end{array}$ & $\begin{array}{l}-0.037 \\
{[0.002]}\end{array}$ & $\begin{array}{c}-0.012 \\
{[0.259]}\end{array}$ & $\begin{array}{r}-0.010 \\
{[0.462]}\end{array}$ & $\begin{array}{c}-0.014 \\
{[0.017]}\end{array}$ \\
\hline Complete secondary & $\begin{array}{r}-0.005 \\
{[0.769]}\end{array}$ & $\begin{array}{c}-0.016 \\
{[0.088]}\end{array}$ & $\begin{array}{r}-0.025 \\
{[0.174]}\end{array}$ & $\begin{array}{c}-0.023 \\
{[0.015]}\end{array}$ & $\begin{array}{c}-0.022 \\
{[0.295]}\end{array}$ & $\begin{array}{c}-0.017 \\
{[0.144]}\end{array}$ & $\begin{array}{c}-0.025 \\
{[0.028]}\end{array}$ & $\begin{array}{r}-0.009 \\
{[0.459]}\end{array}$ & $\begin{array}{c}-0.025 \\
{[0.144]}\end{array}$ & $\begin{array}{r}-0.039 \\
{[0.002]}\end{array}$ & $\begin{array}{c}-0.058 \\
{[0.008]}\end{array}$ & $\begin{array}{c}-0.035 \\
{[0.021]}\end{array}$ & $\begin{array}{c}-0.045 \\
{[0.008]}\end{array}$ & $\begin{array}{r}-0.018 \\
{[0.322]}\end{array}$ & $\begin{array}{c}-0.017 \\
{[0.054]}\end{array}$ \\
\hline Higher than secondary & $\begin{array}{r}0.006 \\
{[0.630]}\end{array}$ & $\begin{array}{l}-0.016 \\
{[0.093]}\end{array}$ & $\begin{array}{c}-0.074 \\
{[0.005]}\end{array}$ & $\begin{array}{c}-0.011 \\
{[0.388]}\end{array}$ & $\begin{array}{r}-0.043 \\
{[0.079]}\end{array}$ & $\begin{array}{r}-0.014 \\
{[0.217]}\end{array}$ & $\begin{array}{l}-0.027 \\
0.104\end{array}$ & $\begin{array}{l}-0.014 \\
0.430\end{array}$ & $\begin{array}{l}-0.012 \\
{[0.439]}\end{array}$ & $\begin{array}{l}-0.045 \\
{[0.002]}\end{array}$ & $\begin{array}{l}-0.040 \\
{[0.099]}\end{array}$ & $\begin{array}{l}-0.023 \\
{[0.222]}\end{array}$ & $\begin{array}{r}-0.039 \\
\lceil 0.017\rceil\end{array}$ & $\begin{array}{l}-0.008 \\
\lceil 0.704\rceil\end{array}$ & $\begin{array}{r}-0.032 \\
{[0.001]}\end{array}$ \\
\hline Mother's age $=15$ years & -0.015 & -0.015 & -0.010 & -0.013 & -0.021 & -0.010 & -0.012 & -0.011 & -0.011 & -0.011 & -0.017 & -0.013 & -0.012 & -0.008 & -0.009 \\
\hline Mother's age $=25$ years & -0.008 & -0.008 & -0.004 & -0.005 & 0.000 & -0.006 & -0.005 & -0.006 & -0.005 & -0.005 & -0.005 & -0.005 & -0.004 & -0.001 & -0.004 \\
\hline $\begin{array}{l}\text { The } p \text {-values for the linear } \\
\text { and quadratic terms of } \\
\text { mother's age resnectively }\end{array}$ & $\begin{array}{l}{[0.000]} \\
{[0.000]}\end{array}$ & $\begin{array}{l}{[0.000]} \\
{[0.000]}\end{array}$ & $\begin{array}{l}{[0.007]} \\
{[0.035]}\end{array}$ & $\begin{array}{l}{[0.000]} \\
{[0.000]}\end{array}$ & $\begin{array}{l}{[0.000]} \\
{[0.006]}\end{array}$ & $\begin{array}{l}{[0.000]} \\
{[0.018]}\end{array}$ & $\begin{array}{l}{[0.001]} \\
{[0.006]}\end{array}$ & $\begin{array}{l}{[0.017]} \\
{[0.085]}\end{array}$ & $\begin{array}{l}{[0.003]} \\
{[0.018]}\end{array}$ & $\begin{array}{l}{[0.001]} \\
{[0.016]}\end{array}$ & $\begin{array}{l}{[0.000]} \\
{[0.000]}\end{array}$ & $\begin{array}{l}{[0.000]} \\
{[0.001]}\end{array}$ & $\begin{array}{l}{[0.000]} \\
{[0.001]}\end{array}$ & $\begin{array}{l}{[0.007]} \\
{[0.008]}\end{array}$ & $\begin{array}{l}{[0.048]} \\
{[0.783]}\end{array}$ \\
\hline Multiple birth & $\begin{array}{c}0.264 \\
{[0.000]}\end{array}$ & $\begin{array}{c}0.213 \\
{[0.000]}\end{array}$ & $\begin{array}{c}0.225 \\
{[0.000]}\end{array}$ & $\begin{array}{c}0.188 \\
{[0.000]}\end{array}$ & $\begin{array}{c}0.168 \\
{[0.000]}\end{array}$ & $\begin{array}{c}0.183 \\
{[0.000]}\end{array}$ & $\begin{array}{c}0.141 \\
{[0.000]}\end{array}$ & $\begin{array}{c}0.104 \\
{[0.000]}\end{array}$ & $\begin{array}{c}0.196 \\
{[0.000]}\end{array}$ & $\begin{array}{c}0.140 \\
{[0.000]}\end{array}$ & $\begin{array}{c}0.205 \\
{[0.000]}\end{array}$ & $\begin{array}{c}0.208 \\
{[0.000]}\end{array}$ & $\begin{array}{c}0.142 \\
{[0.000]}\end{array}$ & $\begin{array}{c}0.078 \\
{[0.000]}\end{array}$ & $\begin{array}{c}0.120 \\
{[0.393]}\end{array}$ \\
\hline Birth-order 3 & 0.005 & 0.003 & -0.003 & 0.002 & 0.020 & -0.002 & -0.008 & 0.010 & -0.010 & -0.006 & 0.011 & 0.025 & 0.004 & -0.020 & 0.000 \\
\hline & {$[0.559]$} & {$[0.616]$} & {$[0.796]$} & {$[0.729]$} & {$[0.036]$} & {$[0.791]$} & {$[0.447]$} & {$[0.305]$} & {$[0.303]$} & {$[0.400]$} & {$[0.266]$} & {$[0.005]$} & {$[0.634]$} & {$[0.040]$} & {$[0.138]$} \\
\hline Birth-order 4 & $\begin{array}{c}0.017 \\
{[0.073]}\end{array}$ & $\begin{array}{c}0.022 \\
{[0.006]}\end{array}$ & $\begin{array}{c}-0.008 \\
{[0.532]}\end{array}$ & $\begin{array}{c}0.017 \\
{[0.038]}\end{array}$ & $\begin{array}{c}0.021 \\
{[0.072]}\end{array}$ & $\begin{array}{c}-0.005 \\
{[0.580]}\end{array}$ & $\begin{array}{c}0.016 \\
{[0.185]}\end{array}$ & $\begin{array}{c}0.035 \\
{[0.002]}\end{array}$ & $\begin{array}{c}-0.008 \\
{[0.496]}\end{array}$ & $\begin{array}{c}0.009 \\
{[0.333]}\end{array}$ & $\begin{array}{c}0.024 \\
{[0.058]}\end{array}$ & $\begin{array}{c}0.025 \\
{[0.032]}\end{array}$ & $\begin{array}{c}0.026 \\
{[0.016]}\end{array}$ & $\begin{array}{c}-0.008 \\
{[0.523]}\end{array}$ & $\begin{array}{c}0.017 \\
{[0.016]}\end{array}$ \\
\hline
\end{tabular}




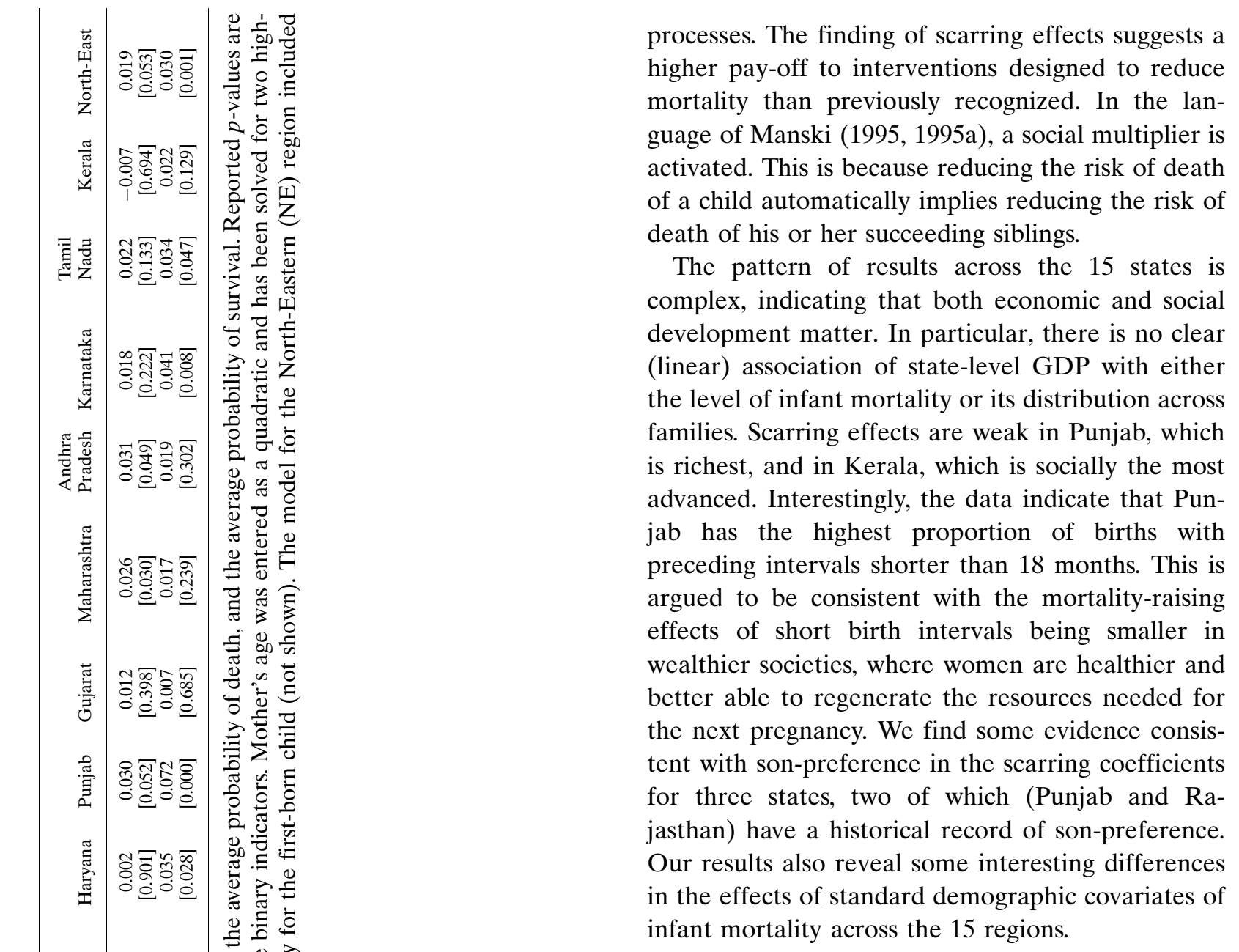

\section{Notes}

1 Wiji Arulampalam is Professor of Economics, Department of Economics, University of Warwick, Coventry CV4 7AL, UK. E-mail: wiji.arulampalam@warwick.ac. uk. Sonia Bhalotra is Reader in Economics, Department of Economics, University of Bristol, 8 Woodland Road, Bristol BS8 1TN, UK. E-mail: s.bhalotra@bristol. ac.uk

2 We acknowledge financial support from the ESRC under Research Grant RES-000-22-0651 and would like to thank ORC Macro International for providing us with the data. We are grateful to Arthur van Soest, Mike Veall, and three anonymous referees for many helpful comments. The paper has benefited from presentation at the Universities of Toronto, McMaster, Tilburg, Essex, and Southampton, the ESRC Econometric Study Group Meeting, and at an international workshop we organized at the University of Bristol on Child Health in Developing Countries. We are grateful to DFID-UK for funding the workshop. An earlier version of this paper was circulated under the title 'Persistence in Infant Mortality: Evidence for the Indian States'. 


\section{Appendix}

Table A1 Sample descriptive statistics, 15 Indian states, 1961-99

\begin{tabular}{|c|c|c|c|c|c|c|c|c|c|c|c|}
\hline State & $\begin{array}{l}\text { Number of } \\
\text { mothers } \\
{[1]}\end{array}$ & $\begin{array}{l}\text { Number of } \\
\text { children } \\
{[2]}\end{array}$ & $\begin{array}{c}\text { Number of } \\
\text { infant deaths } \\
{[3]}\end{array}$ & $\begin{array}{c}\% \text { families } \\
\text { with at least } \\
\text { one infant } \\
\text { death } \\
{[4]}\end{array}$ & $\begin{array}{c}\% \text { children } \\
\text { born in } \\
\text { families that } \\
\text { had at least } \\
\text { one infant } \\
\text { death } \\
{[5]}\end{array}$ & $\begin{array}{c}\% \text { infant } \\
\text { deaths among } \\
\text { under-5 } \\
\text { deaths } \\
{[6]}\end{array}$ & $\begin{array}{c}\% \text { births with } \\
\text { preceding } \\
\text { birth interval } \\
<18 \text { months } \\
{[7]}\end{array}$ & $\begin{array}{c}\text { \% births } \\
\text { with } \\
\text { preceding } \\
\text { birth } \\
\text { interval } \\
18-23 \\
\text { months } \\
\text { [8] }\end{array}$ & $\begin{array}{c}\% \text { births } \\
\text { with } \\
\text { preceding } \\
\text { birth } \\
\text { interval } \\
>23 \text { months } \\
{[9]}\end{array}$ & $\begin{array}{c}\text { Total } \\
\text { fertility, age } \\
15-49: \\
1996-98 \\
{[10]}\end{array}$ & $\begin{array}{c}\text { Mother's age } \\
\text { at first birth } \\
\text { in years } \\
{[11]}\end{array}$ \\
\hline \multicolumn{12}{|l|}{ Central } \\
\hline Madhya Pradesh & 5,543 & 21,403 & 2,428 & 29.9 & 40.9 & 67.5 & 17.6 & 19.6 & 62.6 & 2.61 & 15.3 \\
\hline Uttar Pradesh & 7,297 & 29,937 & 3,485 & 30.8 & 42.0 & 73.1 & 18.1 & 18.6 & 63.1 & 2.88 & 15.7 \\
\hline \multicolumn{12}{|l|}{ East } \\
\hline Orissa & 3,655 & 11,722 & 1,236 & 23.9 & 33.0 & 78.1 & 14.8 & 17.3 & 67.7 & 2.19 & 16.8 \\
\hline Bihar & 5,629 & 21,374 & 1,709 & 20.6 & 28.4 & 67.9 & 13.9 & 19.8 & 67.2 & 2.75 & 15.8 \\
\hline West Bengal & 3,606 & 10,627 & 807 & 16.1 & 25.9 & 77.3 & 14.4 & 18.5 & 66.8 & 1.69 & 16.2 \\
\hline \multicolumn{12}{|l|}{ North } \\
\hline Rajasthan & 5,424 & 20,774 & 2,079 & 26.5 & 36.2 & 70.6 & 17.3 & 21.0 & 61.6 & 2.98 & 15.9 \\
\hline Haryana & 2,436 & 8,105 & 535 & 16.3 & 23.2 & 72.7 & 16.4 & 21.1 & 62.4 & 2.24 & 17.3 \\
\hline Punjab & 2,390 & 7,211 & 429 & 13.9 & 20.9 & 79.9 & 20.8 & 20.5 & 58.3 & 1.79 & 19.1 \\
\hline \multicolumn{12}{|l|}{ West } \\
\hline Gujarat & 3,192 & 10,326 & 879 & 20.5 & 29.2 & 73.7 & 15.7 & 22.0 & 62.1 & 2.33 & 17.1 \\
\hline Maharashtra & 4,283 & 12,881 & 759 & 14.3 & 21.2 & 73.5 & 14.0 & 20.1 & 65.6 & 2.24 & 16.4 \\
\hline \multicolumn{12}{|l|}{ South } \\
\hline Andhra Pradesh & 3,233 & 10,129 & 928 & 20.6 & 29.6 & 78.4 & 16.7 & 19.6 & 63.4 & 2.07 & 15.0 \\
\hline Karnataka & 3,472 & 11,174 & 854 & 18.0 & 26.1 & 71.0 & 13.4 & 23.4 & 63.0 & 1.89 & 16.0 \\
\hline Tamil Nadu & 3,870 & 10,405 & 737 & 15.0 & 23.1 & 73.4 & 15.7 & 18.4 & 65.6 & 2.11 & 17.6 \\
\hline Kerala & 2,340 & 5,950 & 212 & 7.6 & 12.3 & 79.6 & 15.0 & 17.5 & 67.2 & 1.51 & 18.9 \\
\hline North-East & 9,370 & 31,684 & 1,933 & 15.6 & 23.1 & 73.1 & 14.5 & 20.3 & 65.1 & 2.08 & 18.1 \\
\hline
\end{tabular}




\begin{tabular}{|c|c|c|c|c|c|c|c|c|c|}
\hline State & $\begin{array}{c}\text { Religion: } \\
\text { Hindu (\%) } \\
\text { [12] }\end{array}$ & $\begin{array}{c}\text { Caste: scheduled } \\
\text { caste/tribe }(\%) \\
{[13]}\end{array}$ & $\begin{array}{c}\text { Mother's } \\
\text { education- } \\
\text { none }(\%) \\
{[14]}\end{array}$ & $\begin{array}{c}\text { Mother's } \\
\text { education- } \\
\text { secondary or } \\
\text { higher (\%) } \\
{[15]}\end{array}$ & $\begin{array}{c}\text { Father's } \\
\text { education- } \\
\text { none }(\%) \\
{[16]}\end{array}$ & $\begin{array}{c}\text { Father's } \\
\text { education-- } \\
\text { secondary or } \\
\text { higher }(\%) \\
{[17]}\end{array}$ & $\begin{array}{c}\text { \% with no } \\
\text { electricity } \\
{[18]}\end{array}$ & $\begin{array}{l}\text { \% female } \\
\text { children } \\
\text { [19] }\end{array}$ & $\begin{array}{c}\text { Rank of state in } \\
\text { income per head } \\
{[20]}\end{array}$ \\
\hline \multicolumn{10}{|l|}{ Central } \\
\hline Madhya Pradesh & 91.2 & 38.3 & 71.5 & 5.8 & 34.4 & 18.7 & 30.1 & 47.9 & 12 \\
\hline Uttar Pradesh & 82.3 & 21.7 & 75.5 & 6.3 & 33.8 & 29.1 & 63.6 & 47.5 & 13 \\
\hline \multicolumn{10}{|l|}{ East } \\
\hline Orissa & 95.5 & 39.8 & 60.2 & 5.1 & 33.4 & 16.4 & 60.6 & 48.3 & 14 \\
\hline Bihar & 81.3 & 28.5 & 81.2 & 4.9 & 46.2 & 25.5 & 82.8 & 47.9 & 15 \\
\hline West Bengal & 72.7 & 29.0 & 50.3 & 8.7 & 31.2 & 19.1 & 57.1 & 48.5 & 9 \\
\hline \multicolumn{10}{|l|}{ North } \\
\hline Rajasthan & 88.1 & 33.2 & 80.9 & 4.0 & 40.5 & 22.5 & 37.3 & 47.8 & 11 \\
\hline Haryana & 88.2 & 23.0 & 66.6 & 12.7 & 34.2 & 35.0 & 12.1 & 46.0 & 3 \\
\hline Punjab & 43.1 & 31.1 & 46.5 & 22.4 & 27.1 & 37.4 & 3.9 & 45.6 & 1 \\
\hline \multicolumn{10}{|l|}{ West } \\
\hline Gujarat & 89.8 & 38.0 & 56.3 & 12.1 & 26.2 & 25.4 & 16.5 & 48.1 & 4 \\
\hline Maharashtra & 73.8 & 22.6 & 41.6 & 14.5 & 19.8 & 30.7 & 13.9 & 47.9 & 2 \\
\hline \multicolumn{10}{|l|}{ South } \\
\hline Andhra Pradesh & 85.5 & 26.2 & 67.6 & 7.1 & 47.0 & 18.7 & 24.1 & 48.2 & 8 \\
\hline Karnataka & 83.3 & 24.7 & 60.5 & 10.9 & 39.9 & 22.7 & 19.4 & 48.7 & 7 \\
\hline Tamil Nadu & 87.2 & 26.5 & 40.5 & 11.9 & 22.1 & 23.8 & 18.4 & 48.4 & 5 \\
\hline Kerala & 47.3 & 9.8 & 11.4 & 27.7 & 7.8 & 27.0 & 27.9 & 48.1 & 6 \\
\hline North-East & 44.3 & 56.8 & 46.4 & 8.7 & 27.6 & 20.0 & 44.1 & 48.2 & 10 \\
\hline
\end{tabular}

Source: National Family Health Survey II, 1998-99, except Column [20] which is from Government of India (2003): Economic Survey 2002-2003, Table 1.8: per capita net state domestic product. For the North-Eastern region, the rank is based on an unweighted average of the figures for the individual states. 


\section{References}

Aizer, Anna and Janet Currie. 2004. Networks or neighborhoods? Correlations in the use of publicly-funded maternity care in California, Journal of Public Economics 88(12): 2573-2585.

Altonji, Joseph G. and Thomas A. Dunn. 1996. Using siblings to estimate the effect of school quality on wages, The Review of Economics and Statistics 78(4): 665-671.

Andrews, Donald W. K. 2001. Testing when a parameter is on the boundary of the maintained hypothesis, Econometrica 69(3): 683-734.

Arulampalam, Wiji and Sonia Bhalotra. 2004. Inequality in infant survival rates in India: identification of statedependence effects. Discussion Paper 04/558, Department of Economics, University of Bristol.

Arulampalam, Wiji and Sonia Bhalotra. 2006. Sibling death clustering in India: state dependence vs unobserved heterogeneity, Journal of the Royal Statistical Society, Series A 169(4): 829-848.

Behrman, Jere R. and Barbara L. Wolfe. 1984. The socioeconomic impact of schooling in a developing country, The Review of Economics and Statistics 66(2): 296-303.

Bhalotra, Sonia and Arthur van Soest. 2008. Birth-spacing, fertility and neonatal mortality in India: dynamics, frailty and fecundity, Journal of Econometrics 143(2): 274-290.

Black, Robert E., Saul S. Morris, and Jennifer Bryce. 2003. Where and why are 10 million children dying every year?, Lancet 361(9376): 2226-2234.

Bolstad, William M. and Samuel O. Manda. 2001. Investigating child mortality in Malawi using family and community random effects: a Bayesian analysis, Journal of the American Statistical Association 96(453): 12-19.

Bongaarts, John and Robert G. Potter. 1983. Fertility, Biology and Behaviour: An Analysis of the Proximate Determinants. New York: Academic Press.

Butcher, Kristin F. and Anne Case. 1994. The effect of sibling sex composition on women's education and earnings, The Quarterly Journal of Economics 109(3): $531-563$

Chamberlain, Gary. 1984. Panel data, in S. Griliches and M. Intriligator (eds.), Handbook of Econometrics. Amsterdam: North-Holland, pp. 1247-1318.

Claeson, Mariam, Eduard Bos, Tazim Mawji, and Indra Pathmanathan. 2000. Reducing child mortality in India in the new millennium, Bulletin of the World Health Organisation 78(10): 1192-1199.

Cleland, J. G. and Zeba A. Sathar. 1984. The effect of birth spacing on childhood mortality in Pakistan, Population Studies 38(3): 401-418.
Curtis, Sian L., Ian Diamond, and John W. McDonald. 1993. Birth interval and family effects on post-neonatal mortality in Brazil, Demography 33(1): 33-43.

Das Gupta, Monica. 1990. Death clustering, mothers' education and the determinants of child mortality in rural Punjab, India, Population Studies 44(3): 489-505.

Davanzo, Julie and Anne R. Pebley. 1993. Maternal depletion and child survival in Guatamala and Malaysia, RAND - Labor and Population Program Working Papers 93-18. Rand: Santa Monica CA.

Dreze, Jean and Amartya Sen. 1997. Indian Development: Selected Regional Perspectives. Oxford: Clarendon Press.

Gang, Ira N., Kunal Sen, and Myeong-Su Yun. 2002. Caste, ethnicity and poverty in rural India. Discussion Paper No. 629. Bonn: IZA.

Government of India. 2003. Economic Survey: 2002-2003.

Guo, Guang. 1993. Use of sibling data to estimate family mortality effects in Guatemala, Demography 30(1): 1532.

Heckman, James J. 1981. The incidental parameters problem and the problem of initial conditions in estimating a discrete time-discrete data stochastic process, in Charles F. Manski and Daniel L. McFadden (eds.), Structural Analysis of Discrete Data with Econometric Applications. Cambridge, MA: MIT Press, pp. 114-178.

Heckman, James J. and Burton Singer. 1984. A method for minimizing the impact of distributional assumption in econometric models for duration data, Econometrica 52(2): 271-320.

Heckman, James J., V. Joseph Hotz, and James R. Walker. 1985. New evidence on the timing and spacing of births, American Economic Review 75(2): 179-184.

IIPS and ORC Macro. 2000. National Family Health Survey (NFHS-2) 1998-9: India. Mumbai: International Institute for Population Sciences (IIPS) and Calverton: ORC Macro.

Kaestner, Robert. 1997. Are brothers really better? Sibling sex composition and achievement revisited, Journal of Human Resources 32(2): 250-284.

Kennedy, Kathy I. and Cynthia M. Visness. 1992. Contraceptive efficacy of lactational amenorrhoea, Lancet 339(8787): 227-230.

Lancet. 2003. Special issues on Child Survival, Volumes 359-363.

Manski, Charles F. 1995. Identification Problems in the Social Sciences. Cambridge, MA: Harvard University Press.

Miller, Barbara D. 1981. The Endangered Sex: Neglect of Female Children in Rural North India. Ithaca, NY: Cornell University Press.

Moffitt, Robert A. 2004. Policy interventions, low-level equilibria and social interactions, in Steven N. Durlauf 
and H. Peyton Young (eds.), Social Dynamics. Cambridge, MA: MIT Press.

Narendranathan, Wiji and Peter Elias. 1993. Influences of past history on the incidence of youth unemployment: empirical findings for the UK, Oxford Bulletin of Economics and Statistics 55(2): 161-185.

Neumark, David and Sanders Korenman. 1994. Sources of bias in women's wage equations: results using sibling data, The Journal of Human Resources 29(2): 379-405.

Neyman, J. and Elizabeth L. Scott. 1948. Consistent estimates based on partially consistent observations, Econometrica 16(1): 1-32.

Oettinger, Gerald S. 2000. Sibling similarity in high school graduation outcomes: causal interdependency or unobserved heterogeneity?, Southern Economic Journal 66(3): 631-648.

Pinker, Steven. 2002. The Blank Slate: The Modern Denial of Human Nature. London: Allen Lane/Penguin Press.

Preston, Samuel H. 1985. Mortality in childhood: lessons from WFS, in John Cleland and John Hobcraft (eds.), Reproductive Change in Developing Countries. Oxford: Oxford University Press, pp. 46-59.

Rahman, Atif, Zafar Iqbal, James Bunn, Hermione Lovel, and Richard Harrington. 2004. Impact of maternal depression on infant nutritional status and illness: a cohort study, Archives of General Psychiatry 61(9): 946952.

Rawlings, James S., Virginia B. Rawlings, and John A. Read. 1995. Prevalence of low birth weight and preterm delivery in relation to the interval between pregnancies among white and black women, The New England Journal of Medicine 332(2): 69-74.

Rosenzweig, Mark R. and Kenneth I. Wolpin. 1986. Evaluating the effects of optimally distributed public programs: Child health and family planning interventions, The American Economic Review 76(3): 470-482.

Rosenzweig, Mark R. and Kenneth I. Wolpin. 1994. Are there increasing returns to the intergenerational production of human capital? Maternal schooling and child intellectual achievement, The Journal of Human Resources 29(2): 670-693.

Rutstein, Sean O. 2005. Effects of preceding birth intervals on neonatal, infant and under-five years mortality and nutritional status in developing countries: evidence from the demographic and health surveys, International Journal of Gynecology and Obstetrics 89(1): S7-S24.
Sastry, Narayan. 1997. Family-level clustering of childhood mortality risk in Northeast Brazil, Population Studies 51(3): 245-261.

Self, Steven G. and Kung-Yee Liang. 1987. Asymptotic properties of maximum likelihood estimators and likelihood ratio tests under nonstandard conditions, Journal of the American Statistical Society 82(398): 605-610.

Solon, Gary, Mary Corcoran, Roger H. Gordon, and Deborah Laren. 1991. A longitudinal analysis of sibling correlations in economic status, The Journal of Human Resources 26(3): 509-534.

Stata 8. 2004. Stata Statistical Software. College Station Tx: StataCorp LP.

Steer, Robert A., Theresa O. Scholl, Mary L. Hediger, and Richard L. Fischer. 1992. Self-reported depression and negative pregnancy outcomes, Journal of Clinical Epidemiology 45(10): 1093-1099.

Stephansson, Olof, Paul W. Dickman, and Sven Cnattingius. 2003. The influence of interpregnancy interval on the subsequent risk of stillbirth and early neonatal death, Obstetrics Gynaecology 102(1): 101-108.

Strauss, John and Duncan Thomas. 1995. Human resources: empirical modelling of household and family decisions, in Jere Behrman and T. N. Srinivasan (eds.), Handbook of Development Economics, Volume 3A. Amsterdam: North-Holland, pp. 1883-2023.

UNDP. 2003. Human Development Report: Millennium Development Goals: A Compact Among Nations to End Human Poverty.

Wooldridge, Jeffrey M. 2002. Econometric Analysis of Cross Section and Panel Data. Cambridge, MA: MIT Press.

Wooldridge, Jeffrey M. 2005. A simple solution to the initial conditions problem in dynamic, nonlinear panel data models with unobserved heterogeneity, Journal of Applied Econometrics 20(1): 30-54.

World Bank. 2004. Attaining the Millennium Development Goals in India: How Likely and What will it take to Reduce Infant Mortality, Child Malnutrition, Gender Disparities and Hunger-Poverty and to Increase School Enrolment and Completion? Human Development Unit, South Asia Region, April.

Zenger, Elizabeth. 1993. Siblings' neonatal mortality risks and birth spacing in Bangladesh, Demography 30(3): 477-488. 